\title{
Association between Soil Fertility and Growth Performance of Planted Shorea macrophylla (de Vriese) after Enrichment Planting at Rehabilitation Sites of Sampadi Forest Reserve, Sarawak, Malaysia
}

\author{
Mugunthan Perumal, ${ }^{1}$ Mohd Effendi Wasli, ${ }^{1}$ Ho Soo Ying, ${ }^{1}$ \\ Jonathan Lat, ${ }^{2}$ and Hamsawi Sani ${ }^{1}$ \\ ${ }^{1}$ Department of Plant Science and Environmental Ecology, Faculty of Resource Science and Technology, Universiti Malaysia Sarawak, \\ 94300 Kota Samarahan, Sarawak, Malaysia \\ ${ }^{2}$ Forest Department of Sarawak, Wisma Sumber Alam, Petra Jaya, 93660 Kuching, Sarawak, Malaysia
}

Correspondence should be addressed to Mugunthan Perumal; mugunthanperumal89@gmail.com

Received 6 July 2017; Revised 20 September 2017; Accepted 31 October 2017; Published 28 November 2017

Academic Editor: Kurt Johnsen

Copyright ( 2017 Mugunthan Perumal et al. This is an open access article distributed under the Creative Commons Attribution License, which permits unrestricted use, distribution, and reproduction in any medium, provided the original work is properly cited.

\begin{abstract}
A study was conducted to determine the status of soil properties after enrichment planting in comparison to an adjacent secondary forest and to evaluate the effect of enrichment planting of Shorea macrophylla (de Vriese) on the soil fertility status with special reference to Soil Fertility Index (SFI) and Soil Evaluation Factor (SEF) at Sampadi Forest Reserve, Sarawak. The study sites were stands rehabilitated in different years (1996: SM96; 1997: SM97; 1998: SM98; 1999: SM99) and secondary forest (SF). Findings indicated that the soils at rehabilitation sites and SF were strongly acidic in nature, with $\mathrm{pH}$ less than 5.50, poor soil exchangeable bases, and nutrient status. The soils were relatively of sandy clay loam to sandy clay. Principal Component Analysis revealed the three most significant components of the soil properties which explained $76.3 \%$ of the total variation. At surface soils, SFI was correlated with tree growth parameters of S. macrophylla, indicating that SFI is an applicable soil quality index as compared to SEF. Notwithstanding, a significant association was found between soil available phosphorus and planted S. macrophylla, indicating that soil phosphorus is a better indicator than SFI. Further studies on other environmental factors influencing tree growth performance, early establishment of experimental reforestation at nursery, and field should be implemented to obtain the initial data on seedling growth performance prior to outplanting.
\end{abstract}

\section{Introduction}

Many countries throughout the world are facing acute scarcity of lands for food production due to the rapid increase of population and limited land resources, which causes people to convert forestland into agricultural, horticultural, plantations, and pastoral land for cattle settlements or mining [1]. Such human activities have led to the depletion of existing forests throughout the world, particularly in Asian countries. In the tropics, approximately $60 \%$ or 850 million hectares of the total forest area between the year 1950 and 2000 have been degraded and are difficult to regenerate due to chemical, biological, and physical barriers [2]. Consequently, this has led to the attention of developing restoration or rehabilitation practices on degraded secondary forest [3-7] as to preclude further degradation $[8,9]$ by means of improving the site productivity and quality $[10,11]$. According to Doi and Sakurai [12], measuring soil quality using soil indices is essential to estimate the soil productivity or to rehabilitate degraded lands. Enrichment planting system has been used as one of the promising techniques to recover and restore the degraded forestland in the tropics $[3,13,14]$.

Restoration of degraded forestland is indispensable to reduce soil nutrient loss and improve vegetation composition 
or stand for the purpose of environmental conservation [15]. Rehabilitation efforts in degraded forestland due to abandoned shifting cultivation have been successfully implemented under the ecosystem rehabilitation [16] and by enrichment planting technique $[17,18]$ in Sarawak, Malaysia. In Sarawak, one of the common indigenous tree species from Dipterocarpaceae family, Shorea macrophylla (de Vriese), was considered and selected for forest rehabilitation purposes $[18,19]$. This climax species was chosen since it is one of the fastest growing species of the genus Shorea and is found frequently along rivers and in areas which are periodically inundated. Likewise, in Peninsular Malaysia, rehabilitation of forestland that is degraded due to excessive harvesting has been reforested through the technique of enrichment planting [20-23].

Knowledge of soil science for the better understanding of the effective soil management and conservation is required for the rehabilitation of tropical rainforest on the land that is severely degraded. Consequently, a multivariate strategy can be implemented to measure the soil quality. Since properties of the same soil may respond differently to a degrading impact [24], it is expected to be more informative to quantify and integrate various soil variables than measuring a single variable [12]. A multivariate soil data set is regarded as integrated properties of the soil. According to Sena et al. [25], integrating multiple soil physicochemical properties with the use of a multivariate statistical technique often provides new measures that explain variations among the soils.

Principal Component Analysis (PCA) is one of the proposed multivariate statistical techniques used to measure and explain the differences among soils. In PCA, a multivariate data set is analyzed to reduce the original complicated dimensionality and to give a few principal components (PCs) that explain the variation in the data $[12,21]$. Thus, data redundancy is avoided and the most significant PCs which explain the difference are specified. Previous studies have emphasized using PCA to identify PCs and important soil physicochemical properties relating to the incidence of plant disease [26], soil formation reflecting landscape [27], and other types of gradient.

However, for the case of Sarawak, Malaysia, intensive research has to be done on the elucidation of soil properties based on PCA and soil indices after enrichment planting in relation to the productivity of the potential dipterocarp species in rehabilitating degraded forestland. Moreover, attention has to be paid to the status of soil physicochemical properties after rehabilitation since most of the previous researches have underlined the growth performance of planted species along with the different technique of planting $[19,28]$. In addition, information on the soilplant relationship of indigenous species and soil fertility status which might influence the survivorship and growth performance of planted species under rehabilitation even after 14 years of the research is necessary for future forest management programmes. On the other hand, Hamzah et al. [23] stated that more comprehensive research has to be conducted on site productivity which could be improved by clarifying the potential of dipterocarp species in rehabilitating degraded forestland.
Therefore, in order to improve strategies and effective technique for future rehabilitation efforts, an evaluation study of the rehabilitation programme in relation to growth performance of planted species and soil fertility status by using PCA and soil indices could deliver significant information on species site preference [21]. The main emphasis was placed on finding the significant soil properties based on PCA and the applicability of the proposed indices, the Soil Fertility Index (SFI) [29] and the Soil Evaluation Factor (SEF) [30] as an alternative approach of indicator for estimating soil fertility and site quality in the plantation for rehabilitation purposes in relation to the survivorship and growth performance of the planted species. Lu et al. [30] mentioned that, for a homogeneous forest with similar vegetation ages, soil indices are often used to evaluate the soil conditions, and the dominant tree height is usually used to model the site indices.

Hence, the aim of this study was to determine the status of soil physicochemical properties under enrichment planting in comparison to an adjacent secondary forest at Sampadi Forest Reserve, Lundu, Sarawak, Malaysia. In addition, the present study also intended to evaluate the effect of enrichment planting of Shorea macrophylla (de Vriese) on the soil fertility status with special reference to Soil Fertility Index (SFI) and Soil Evaluation Factor (SEF). These indices suggested the applicability to the estimation of soil fertility and to the prediction of the increase in biomass, in Amazonian humid tropical forests under secondary succession. The score on the PC, as a measure of changes of soil physicochemical properties after enrichment planting, correlates with the SFI and/or the SEF was investigated.

\section{Materials and Methods}

2.1. Background and Information on Sampadi Forest Reserve Rehabilitation Sites and Secondary Forest. The present study was conducted in a forest under enrichment planting at Sampadi Forest Reserve, Lundu, Sarawak $\left(\mathrm{N} 01^{\circ} 34^{\prime} 13^{\prime \prime} \mathrm{E} 109^{\circ} 53^{\prime} 12^{\prime \prime}\right)$ and adjacent secondary forest $\left(\mathrm{N} 01^{\circ} 30^{\prime} 26.2^{\prime \prime} \mathrm{E} 109^{\circ} 58^{\prime} 56.7^{\prime \prime}\right.$ ) which is located about $72 \mathrm{~km}$ southwest of Kuching City (Figure 1). The area covers approximately 5,163 hectares with an average elevation of $87 \mathrm{~m}$ above sea level. The topography at the rehabilitation sites and secondary forest is of the low undulating type. Sampadi Forest Reserve has a humid subtropical seasonal climate and wet forest biozone (no dry season) with all months receiving on average more than $100 \mathrm{~mm}$ of precipitation [6]. In the early hours of the morning, the average surface annual temperature in the area is $22^{\circ} \mathrm{C}\left(72^{\circ} \mathrm{F}\right)$, and during mid-afternoon, it rises to around $31^{\circ} \mathrm{C}\left(88^{\circ} \mathrm{F}\right)$ with little monthly variation $[31,32]$. According to our previous study at the area, the morphological characteristics of the soils resemble Bako soil series as a dominant unit in association with Saratok series and are categorized mainly under the soil group of Grey-White Podzolic Soil based on the Sarawak soil classification system $[19,31]$. The soils in the study area were derived from a mixture of sandstone, coarse-grained, humult ultisols, and sandy residual parent material [19, 28]. Based on the USDA-NRCS classification system, this soil 


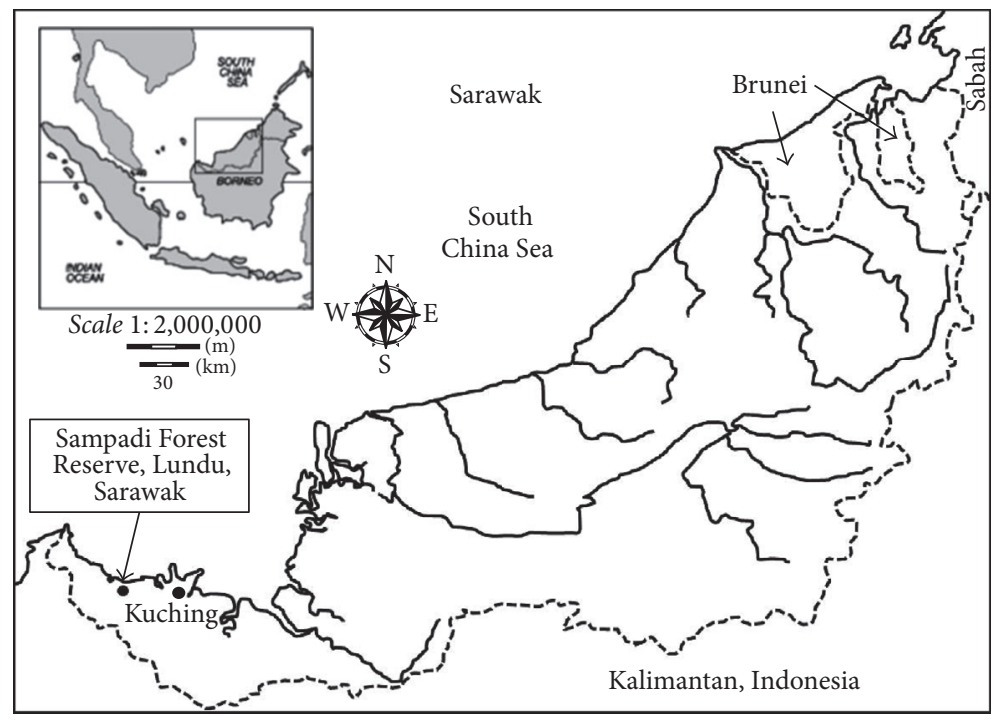

Figure 1: Location of the study area: Sampadi Forest Reserve, Lundu, Sarawak. Perumal et al. [18].

group corresponds to Typic Paleaquults of Soil Taxonomy $[19,33,34]$.

Based on the general in situ observation, the current stand characteristics of the secondary forests and forest within the enrichment planting were almost similar. According to Forest Department of Sarawak [35], the Sampadi Forest Reserve is comprised predominantly of Mixed Dipterocarp Forest (MDF) and followed by Kerangas forest that had been logged over with some riparian forest found along the main rivers or streams of Batang Kayan. The existing Mixed Dipterocarp Forest (MDF) within the research area had been logged since the year 1970-1980s and most of the forests have lost their form and structure. The upper storey of the MDF was represented by relic stands of large trees between 30 and $35 \mathrm{~m}$ tall and the diameter between 60 and $90 \mathrm{~cm}$. The dominant emergents were Meranti, Lun and Selangan batu (Shorea sp.), Keruing (Dipterocarpus sp.), Menggris (Koompassia malaccensis), Tapang (Koompassia excelsa), Tampar hantu (Sindora spp.), and Geronggang (Cratoxylum arborescens). The midstorey was dominated by sparse clusters of smaller trees attaining heights of $15-25 \mathrm{~m}$ and diameter of $30-50 \mathrm{~cm}$ such as Empenit (Lithocarpus sp.), Kayu massam (Aporusa sp.), Kayu malam (Diospyros sp.), and Ubah (Eugenia sp.). The lower storey was occupied by dense thickets of small trees and regeneration of larger species. The presence of skid trail and the logging gaps creates dense colonization by woody and nonwoody pioneer tree species. Woody species are represented by Benua (Macaranga sp.), Kelampayan (Anthocephalus chinensis), Kayu ara (Ficus sp.), Sabar besi (Callicarpa sp.), and Buan or Simpor (Dillenia suffruticosa) and nonwoody species are represented by Paku kelindang (Blechnum orientale), wild ginger (Alpinia sp., Amomum sp., and Costus sp.), and Daun long (Phrynium sp.).

Pockets of Kerangas forest remained generally undisturbed due to the presence of very poor podzolized soils. Among the tree species typical of this forest were Somah (Ploiarium alternifolium) and Geronggang biabas (Cratoxylum formosum) which were small in diameter and rarely attain the height of eight meters. The riparian forest along the major rivers or streams had lost their original forms and structure through shifting agriculture or past logging activities. The preparation of sites prior to the plantation establishment and planting technique used were mentioned and explained in the previous study $[18,28]$. The planted species in the study area were mainly from Dipterocarpaceae family such as Engkabang jantong (Shorea macrophylla), Meranti sarang punai (Shorea parvifolia), Selangan batu (Shorea falcifera), Kapur bukit (Dryobalanops beccarii), and Bintangor bukit (Calophyllum alboramulum).

2.2. Experimental Design and Methods for Soil Sampling. In order to clarify the soil properties in greater detail, six experimental plots sized $25 \mathrm{~m} \times 25 \mathrm{~m}$ in the rehabilitation sites were constructed for stands of six ages. Abbreviations were applied to represent the studied plots as follows: planted with Shorea macrophylla in the year 1996: SM96; 1997: SM97; 1998: SM98; and 1999: SM99. Study plots sized $20 \mathrm{~m} \times 20 \mathrm{~m}$ were established for soil sampling at the adjacent secondary forest (SF; 30 years) outside the rehabilitation areas. For the soil sampling at the rehabilitated areas, soil samples were collected on the planting line at the depth of $0-10 \mathrm{~cm}$ (surface soils) and 30-40 cm (subsurface soils) at three random points within each $25 \mathrm{~m} \times 25 \mathrm{~m}$ plot in each age stands and were mixed well to get a composite sample for each soil layer $[19,28,36]$. Similarly, three random points within the $20 \mathrm{~m}$ $\times 20 \mathrm{~m}$ plots located outside the rehabilitated sites (SF) were designated for soil sampling, and soils were collected at the depth of $0-10 \mathrm{~cm}$ (surface soils) and $30-40 \mathrm{~cm}$ (subsurface soils) and mixed well to get a composite sample for each soil layer. Undisturbed soil samples were collected at the depth of $0-10 \mathrm{~cm}$ and $30-40 \mathrm{~cm}$ using a $100-\mathrm{cc}$ core sampler for the determination of soil physical properties. The general information of each rehabilitation sites and adjacent secondary forest is shown in Table 1. The collected composite soil 
TABLE 1: General information of the study sites; SM96, SM97, SM98, SM99 (rehabilitation sites), and secondary forest (SF).

\begin{tabular}{lcccc}
\hline Study sites & Year planted & GPS location & Species & Planting technique \\
\hline SM96 & 1996 & $\mathrm{~N}^{\circ} 30^{\prime} 15.0^{\prime \prime}, \mathrm{E} 109^{\circ} 55^{\prime} 00.3^{\prime \prime}$ & Shorea macrophylla & Line planting \\
SM97 & 1997 & $\mathrm{~N}^{\circ} 31^{\prime} 12.0^{\prime \prime}, \mathrm{E} 100^{\circ} 54^{\prime} 56.0^{\prime \prime}$ & Shorea macrophylla & Line planting \\
SM98 & 1998 & $\mathrm{~N}^{\circ} 30^{\prime} 12.1^{\prime \prime}, \mathrm{E} 109^{\circ} 54^{\prime} 54.8^{\prime \prime}$ & Shorea macrophylla & Line planting \\
SM99 & 1999 & $\mathrm{~N} 01^{\circ} 30^{\prime} 12.1^{\prime \prime}, \mathrm{E} 109^{\circ} 52^{\prime} 54.3^{\prime \prime}$ & Shorea macrophylla & Line planting \\
SF & Secondary forest & $\mathrm{N}^{\circ} 31^{\prime} 26.2^{\prime \prime}, \mathrm{E} 109^{\circ} 58^{\prime} 56.7^{\prime \prime}$ & Naturally grown secondary \\
\end{tabular}

samples were air-dried for a week, crushed, and homogenized and all the plant materials such as fine roots, leaves, and twigs were carefully removed. Later, the air-dried soil samples were passed through a $2 \mathrm{~mm}$ mesh sieve before use for further soil physicochemical analyses.

2.3. Methods for Soil Physicochemical Analyses. Soil pH $\left(\mathrm{H}_{2} \mathrm{O}\right)$ was determined in water and $\mathrm{pH}(\mathrm{KCl})$ in $1 \mathrm{M}$ $\mathrm{KCl}$ in a soil to solution ratio of $1: 5$ by glass electrode method. Electrical conductivity (EC) of soil was measured using the supernatant solution after reciprocal shaking for 1 hour at the soil to water ratio of $1: 5$ and examined using conductivity meter (Eutech Instruments-Cyberscan Con 11). The filtrate from the $\mathrm{pH}(\mathrm{KCl})$ measurement was used for soil exchangeable $\mathrm{Al}$ analysis. Exchange acidity $(\mathrm{Al}+\mathrm{H})$ was determined using the titration method with $0.01 \mathrm{M}$ $\mathrm{NaOH}$ and the content of the exchangeable $\mathrm{Al}$ with $0.01 \mathrm{M}$ $\mathrm{HCl}$ [37]. Total carbon (Total C) and organic matter (OM) contents in soil were determined using the loss on ignition method $[38,39]$. In addition, the soil total nitrogen (Total N) content was determined by Kjeldahl acid digestion method [40]. The contents of soil exchangeable bases (Ca, Mg, K, and $\mathrm{Na}$ ) and soil cation exchange capacity (CEC) were measured after three times of successive extraction using $1 \mathrm{M}$ ammonium acetate, $\mathrm{NH}_{4}$-OAc adjusted to $\mathrm{pH} 7.0$ and $10 \% \mathrm{NaCl}$, respectively, in a soil to solution ratio of $1: 5$. The contents of soil exchangeable bases were determined by atomic absorption spectrophotometry (Thermo Scientific, ICE Series 3500) for $\mathrm{Ca}, \mathrm{Mg}, \mathrm{K}$, and $\mathrm{Na}$. Steam distillation and titration methods were used to determine the cation exchange capacity of the soil. Available phosphorus (Available P) content in soil was quantified by the Bray II method in a soil to extractant ratio of $1: 20[41,42]$ with UVVis Spectrophotometer at a wavelength of $710 \mathrm{~nm}$ (Jasco V630). Soil particle size distribution was determined using the pipette method [43]. Soil bulk density was determined on the undisturbed samples, collected at each soil horizon depth using a 100-cc core sampler with the ratio of the dry mass of soil to the bulk volume of a soil core. Soil particle density was determined using graduated cylinder method [44]. All soil physicochemical analyses were conducted at the Laboratory of Environmental Soil Science, Faculty of Resource Science and Technology, Universiti Malaysia Sarawak (UNIMAS).

2.4. Statistical Analyses. All data of soil were expressed on an oven-dry basis. In order to indicate the changes of soil physicochemical properties among the rehabilitated sites in relation to the age of Shorea macrophylla since planting, data on soil physicochemical properties at surface and subsurface soils were statistically analyzed and compared using linear regression at $5 \%$ and $1 \%$ levels, respectively. A mathematical model, Principal Component Analysis (PCA), was used to avoid the redundancy of multivariate data and to determine the most prominent soil parameters which had an influence on the fertility of the soils by integrating the soil physicochemical properties. Integrating PCA score with a soil index which represents a soil fertility status is crucial for estimating the soil fertility and quality in humid tropical forests. In this study, two soil indices, the Soil Fertility Index (SFI) [29] and Soil Evaluation Factor (SEF) [30], were used for estimating soil fertility and site quality. Linear regression analysis between the scores on a principal component (PC) as an integrated measure of soil fertility, SFI, or SEF was examined to investigate if the indices can be measures of soil fertility in the rehabilitation sites of Sampadi Forest Reserve. Nonetheless, in this study, linear regression analysis between the PC score, SFI, and SEF as well as tree growth parameters (diameter at breast height and total height) and survival based on our previous study [19] is performed to clarify the soilplant association in order to predict a good indicator for estimating soil fertility and site quality in relation to Shorea macrophylla enrichment planting. All statistical analyses were performed using SPSS version 18.0 for windows. Lu et al. [30] reported that the SFI was applied to measuring soil fertility in an Amazonian humid tropical region. On the other hand, significant correlation was found by Moran et al. [29] between the SFI, as a measure of quality of Amazonian Ultisols or Oxisols, and the succession rate of the secondary tropical forest. In our previous study $[28,45]$, the following equation was used to determine the SFI [29]:

$$
\begin{aligned}
\mathrm{SFI}= & \mathrm{pH}+\text { organic matter }(\%, \text { dry soil basis }) \\
& + \text { available } \mathrm{P}\left(\mathrm{mg} \mathrm{kg}{ }^{-1} \mathrm{dry} \text { soil }\right) \\
& + \text { exchangeable } \mathrm{K}\left(\mathrm{cmol}_{\mathrm{c}} \mathrm{kg}^{-1} \text { dry soil }\right) \\
& + \text { exchangeable } \mathrm{Ca}\left(\mathrm{cmol}_{\mathrm{c}} \mathrm{kg}^{-1} \text { dry soil }\right) \\
& + \text { exchangeable } \mathrm{Mg}\left(\mathrm{cmol}_{\mathrm{c}} \mathrm{kg}^{-1} \text { dry soil }\right) \\
& - \text { exchangeable } \mathrm{Al}\left(\mathrm{cmol}_{\mathrm{c}} \mathrm{kg}^{-1} \text { dry soil }\right) .
\end{aligned}
$$


However, the SFI may largely depend on $\mathrm{pH}$, but an extremely high $\mathrm{pH}$ inhibits plant growth. In addition, $\mathrm{pH}$ is not an independent, but a dependent variable of the relative proportion of $\mathrm{Ca}, \mathrm{Mg}$, and exchangeable $\mathrm{Al}$ concentrations in the soil. A latent drawback of the SFI was pointed out by [30] since the meaning of SFI is not clear. In order to improve this drawback, they developed another index, the Soil Evaluation Factor (SEF), for evaluating status of the Amazonian Ultisols and Oxisols. The SEF values were calculated using the following equation in our previous study:

$$
\begin{aligned}
& \text { SEF }=\left[\text { exchangeable } \mathrm{Ca}\left(\mathrm{cmol}_{\mathrm{c}} \mathrm{kg}^{-1} \text { dry soil }\right)\right. \\
& + \text { exchangeable } \mathrm{Mg}\left(\mathrm{cmol}_{\mathrm{c}} \mathrm{kg}^{-1} \text { dry soil }\right) \\
& + \text { exchangeable } \mathrm{K}\left(\mathrm{cmol}_{\mathrm{c}} \mathrm{kg}^{-1} \text { dry soil }\right)-\log (1 \\
& \left.\left.+ \text { exchangeable } \mathrm{Al}\left(\mathrm{cmol}_{\mathrm{c}} \mathrm{kg}^{-1} \text { dry soil }\right)\right)\right] \\
& \times \text { organic matter }(\%, \text { dry soil basis })+5 .
\end{aligned}
$$

\section{Results and Discussion}

3.1. Soil Physicochemical Properties under Various Age Stands of Rehabilitation Sites and Secondary Forest at Sampadi Forest Reserve, Lundu, Sarawak. The mean average values of soil physicochemical properties of rehabilitation sites (SM96, SM97, SM98, and SM99) and adjacent secondary forest (SF) are presented in Tables 2(a) and 2(b). In general, the soil texture did not vary widely in all the study sites, where most soils were relatively sandy, ranging from sandy clay loam to sandy clay in texture. The content of sand in surface and subsurface soils was fewer than $56 \%$, while that of clay content was above $29 \%$. The clay contents in surface and subsurface soils were 29.0 to $45.9 \%$ and 31.2 to $48.1 \%$, respectively. On the other hand, the sand content in surface and subsurface soils ranged from 29.3 to $53.7 \%$ and 31.4 to $55.2 \%$, respectively. Comparatively, soil organic matter (SOM) in surface soils was relatively higher than that of the subsurface soils. The average SOM values at the surface and subsurface soils ranged from 6.63 to $9.30 \%$ and 3.88 to $5.97 \%$, respectively. The average SOM for the secondary forest (SF) presented higher value in comparison to that of the rehabilitation sites (SM96, SM97, SM98, and SM99).

Soils of all the study sites in Sampadi Forest Reserve could be characterized as strongly acidic, with $\mathrm{pH}\left(\mathrm{H}_{2} \mathrm{O}\right)$ values of less than 5.50 (ranging from 4.67 to 5.29 and 5.01 to 5.38 ) at both surface and subsurface soil layers, respectively. The soil $\mathrm{pH}(\mathrm{KCl})$ of all study sites was moderately acidic at $\mathrm{pH}$ less than 4.50 (ranging from 3.63 to 4.31 and 3.72 to 4.48 ) at both surface and subsurface soil layers, respectively. On the other hand, the soil electrical conductivity at the surface and subsurface soil ranged from 120.0 to $193.6 \mu \mathrm{S} \mathrm{cm}^{-1}$ and 47.5 to $132.9 \mu \mathrm{S} \mathrm{cm}^{-1}$, respectively. In terms of soil total carbon (Total C) and total nitrogen (Total N), the soils in this study had higher values in surface soils than in subsurface soils. The soil Total C value for surface soil ranged from 38.5 to $53.9 \mathrm{~g} \mathrm{~kg}^{-1}$ and that for subsurface soil ranged from 22.6 to $34.6 \mathrm{~g} \mathrm{~kg}^{-1}$. At the depth of $0-10 \mathrm{~cm}$, the Total $\mathrm{N}$ level of soil ranged from
2.16 to $3.05 \mathrm{~g} \mathrm{~kg}^{-1}$, whereas at the depth of $30-40 \mathrm{~cm}$, it ranged from 0.95 to $1.61 \mathrm{~g} \mathrm{~kg}^{-1}$. Generally, the contents of Total C and Total $\mathrm{N}$ in secondary forest (SF) were higher than that of the rehabilitation sites. Among the five study sites, secondary forest showed the highest level of Total C and Total $\mathrm{N}$ at both surface and subsurface soils, which leads to the lower value of C/N ratio as compared to other study sites except in SM99. In spite of high Total $\mathrm{C}$ and Total $\mathrm{N}$ contents in the secondary forest (SF), no clear difference was detected for $\mathrm{C} / \mathrm{N}$ ratio in rehabilitation sites and secondary forest (SF).

In general, the soil cation exchange capacity (CEC) value was low for the surface and subsurface soils for all the rehabilitation sites and secondary forest. The CEC value ranged from 8.4 to $11.8 \mathrm{cmol}_{\mathrm{c}} \mathrm{kg}^{-1}$ in surface soils and ranged from 7.0 to $9.3 \mathrm{cmol}_{\mathrm{c}} \mathrm{kg}^{-1}$ in subsurface soils. For surface soils, the highest value was from SM96 $\left(11.8 \mathrm{cmol}_{\mathrm{c}} \mathrm{kg}^{-1}\right)$, while the lowest value was from SM99 $\left(8.4 \mathrm{cmol}_{\mathrm{c}} \mathrm{kg}^{-1}\right)$. On the other hand, as for the subsurface soils, the highest CEC was from the secondary forest (SF) $\left(9.3 \mathrm{cmol}_{\mathrm{c}} \mathrm{kg}^{-1}\right)$ and the lowest was from SM98 $\left(7.0 \mathrm{cmol}_{\mathrm{c}} \mathrm{kg}^{-1}\right)$.

Throughout the sites, soil exchangeable cations ( $\mathrm{Ca}, \mathrm{Mg}$, and $\mathrm{K}$ ) in surface soils were found higher as compared to the subsurface soils. The soil exchangeable $\mathrm{Ca}$ at surface and subsurface soils ranged from 0.26 to $0.68 \mathrm{cmol}_{\mathrm{c}} \mathrm{kg}^{-1}$ and 0.02 to $0.43 \mathrm{cmol}_{\mathrm{c}} \mathrm{kg}^{-1}$, respectively. The exchangeable $\mathrm{Mg}$ ranged from 0.24 to $0.38 \mathrm{cmol}_{\mathrm{c}} \mathrm{kg}^{-1}$ at surface soils and ranged from 0.11 to $0.15 \mathrm{cmol}_{\mathrm{c}} \mathrm{kg}^{-1}$ at subsurface soils. The exchangeable $\mathrm{K}$ ranged from 0.12 to $0.32 \mathrm{cmol}_{\mathrm{c}} \mathrm{kg}^{-1}$ at surface soils and ranged from 0.06 to $0.25 \mathrm{cmol}_{\mathrm{c}} \mathrm{kg}^{-1}$ at subsurface soils. In comparison to soil exchangeable $\mathrm{Al}$, the exchangeable bases in surface and subsurface soils were low, resulting in a high level of $\mathrm{Al}$ saturation at rehabilitation sites as well as secondary forest. Al saturation was depicted above $40 \%$ at surface soils and more than $60 \%$ at subsurface soils. Comparatively, the soil exchangeable $\mathrm{Al}$ in subsurface soils was greater than the surface soils for rehabilitation sites and secondary forest except for SM98 whereby the soil exchangeable Al contents were greater in surface soils as compared to the subsurface soils. However, in SM99, the soil exchangeable $\mathrm{Al}$ content was the same for surface and subsurface soils. At the depth of $0-10 \mathrm{~cm}$, the soil exchangeable $\mathrm{Al}$ ranged from 1.35 to $4.03 \mathrm{cmol}_{\mathrm{c}} \mathrm{kg}^{-1}$ and ranged from 1.30 to $4.30 \mathrm{cmol}_{c} \mathrm{~kg}^{-1}$ at the depth of $30-40 \mathrm{~cm}$.

The values of soil available $\mathrm{P}$ in surface and subsurface soils ranged from 2.4 to $14.0 \mathrm{mg} \mathrm{P} \mathrm{kg}^{-1}$ and 0.9 to $5.9 \mathrm{mg} \mathrm{P} \mathrm{kg}^{-1}$, respectively. The average soil bulk density of subsurface soils was higher than that of surface soils. The soil bulk density at the depth of $0-10 \mathrm{~cm}$ ranged from 0.90 to $1.08 \mathrm{~g} \mathrm{~mL}^{-1}$ and at the depth of $30-40 \mathrm{~cm}$ ranged from 1.11 to $1.36 \mathrm{~g} \mathrm{~mL}^{-1}$. Secondary forest (SF) had the lowest soil bulk density value $\left(0.90 \mathrm{~g} \mathrm{~mL}^{-1}\right)$ as compared to that of the rehabilitation sites and SM96 had the highest soil bulk density value $\left(1.08 \mathrm{~g} \mathrm{~mL}^{-1}\right)$ at surface soils. At subsurface soils, SM97 depicted the lowest value in soil bulk density $\left(1.11 \mathrm{~g} \mathrm{~mL}^{-1}\right)$ and SM98 depicted the highest value in soil bulk density $\left(1.36 \mathrm{~g} \mathrm{~mL}^{-1}\right)$. 
TABLE 2: (a) Means and standard deviation of surface soil physicochemical properties at rehabilitation sites (SM96, SM97, SM98, and SM99) and secondary forest (SF). (b) Means and standard deviation of subsurface soil physicochemical properties at rehabilitation sites (SM96, SM97, SM98, and SM99) and secondary forest (SF).

(a)

\begin{tabular}{|c|c|c|c|c|c|c|}
\hline \multirow{2}{*}{\multicolumn{2}{|c|}{$\begin{array}{l}\text { Age-since-planting/soil physicochemical } \\
\text { properties }\end{array}$}} & \multicolumn{4}{|c|}{ Rehabilitation sites } & \multirow{2}{*}{$\begin{array}{c}\text { Secondary forest } \\
\text { SF } \\
\text { (30 years) } \\
\end{array}$} \\
\hline & & $\begin{array}{c}\text { SM96 } \\
\text { (18 years) }\end{array}$ & $\begin{array}{c}\text { SM97 } \\
\text { (17 years) }\end{array}$ & $\begin{array}{c}\text { SM98 } \\
\text { (16 years) }\end{array}$ & $\begin{array}{c}\text { SM99 } \\
\text { (15 years) }\end{array}$ & \\
\hline \multicolumn{7}{|c|}{ Surface soil, $0-10 \mathrm{~cm}$ depth } \\
\hline $\mathrm{pH}\left(\mathrm{H}_{2} \mathrm{O}\right)^{* *}$ & & $4.69 \pm 0.12$ & $4.67 \pm 0.09$ & $4.72 \pm 0.08$ & $5.20 \pm 0.06$ & $5.29 \pm 0.26$ \\
\hline $\mathrm{pH}(\mathrm{KCl})^{* *}$ & & $3.92 \pm 0.08$ & $3.63 \pm 0.56$ & $4.07 \pm 0.05$ & $4.31 \pm 0.07$ & $4.16 \pm 0.15$ \\
\hline $\mathrm{EC}^{\mathrm{a} * *}$ & $\left(\mu \mathrm{Scm}^{-1}\right)$ & $120.0 \pm 13.3$ & $163.2 \pm 32.9$ & $165.7 \pm 51.0$ & $193.6 \pm 10.6$ & $188.2 \pm 25.2$ \\
\hline $\mathrm{SOM}^{\mathrm{b}}$ & $(\%)$ & $6.63 \pm 1.71$ & $8.54 \pm 1.51$ & $8.91 \pm 2.06$ & $8.52 \pm 0.83$ & $9.30 \pm 1.40$ \\
\hline Total $C^{c}$ & $\left(\mathrm{~g} \mathrm{~kg}^{-1}\right)$ & $38.5 \pm 9.9$ & $49.6 \pm 8.8$ & $51.7 \pm 12.0$ & $49.4 \pm 4.8$ & $53.9 \pm 8.1$ \\
\hline Total $\mathrm{N}^{\mathrm{d}}$ & $\left(\mathrm{g} \mathrm{kg}^{-1}\right)$ & $2.16 \pm 0.67$ & $2.55 \pm 0.38$ & $2.99 \pm 1.01$ & $2.91 \pm 0.80$ & $3.05 \pm 0.50$ \\
\hline $\mathrm{C} / \mathrm{N}$ ratio & & $18.27 \pm 2.89$ & $19.54 \pm 3.00$ & $18.22 \pm 4.55$ & $17.74 \pm 3.46$ & $17.78 \pm 1.43$ \\
\hline $\mathrm{CEC}^{\mathrm{e} *}$ & $\left(\mathrm{cmol}_{\mathrm{c}} \mathrm{kg}^{-1}\right)$ & $11.8 \pm 2.8$ & $9.7 \pm 1.6$ & $9.5 \pm 1.6$ & $8.4 \pm 3.0$ & $10.2 \pm 1.2$ \\
\hline Exch. $\mathrm{Ca}^{2+}$ & $\left(\mathrm{cmol}_{\mathrm{c}} \mathrm{kg}^{-1}\right)$ & $0.52 \pm 0.17$ & $0.48 \pm 0.25$ & $0.68 \pm 0.25$ & $0.26 \pm 0.28$ & $0.54 \pm 0.43$ \\
\hline Exch. $\mathrm{Mg}^{2+}$ & $\left(\mathrm{cmol}_{\mathrm{c}} \mathrm{kg}^{-1}\right)$ & $0.33 \pm 0.07$ & $0.35 \pm 0.17$ & $0.24 \pm 0.09$ & $0.30 \pm 0.04$ & $0.38 \pm 0.20$ \\
\hline Exch. $\mathrm{K}^{+*}$ & $\left(\mathrm{cmol}_{\mathrm{c}} \mathrm{kg}^{-1}\right)$ & $0.15 \pm 0.04$ & $0.12 \pm 0.02$ & $0.18 \pm 0.03$ & $0.17 \pm 0.03$ & $0.32 \pm 0.03$ \\
\hline Exch. $\mathrm{Al}^{3+* *}$ & $\left(\mathrm{cmol}_{\mathrm{c}} \mathrm{kg}^{-1}\right)$ & $2.54 \pm 0.82$ & $4.03 \pm 0.40$ & $1.35 \pm 0.19$ & $1.56 \pm 0.24$ & $1.40 \pm 0.41$ \\
\hline $\mathrm{SUM}^{\mathrm{f} * *}$ & $\left(\mathrm{cmol}_{\mathrm{c}} \mathrm{kg}^{-1}\right)$ & $1.45 \pm 0.23$ & $1.35 \pm 0.42$ & $1.36 \pm 0.35$ & $0.84 \pm 0.32$ & $1.77 \pm 0.62$ \\
\hline $\mathrm{ECEC}^{\mathrm{g} * *}$ & $\left(\mathrm{cmol}_{\mathrm{c}} \mathrm{kg}^{-1}\right)$ & $3.99 \pm 1.01$ & $5.38 \pm 0.40$ & $2.71 \pm 0.51$ & $2.40 \pm 0.44$ & $3.16 \pm 0.65$ \\
\hline Base saturation & $(\%)$ & $12.6 \pm 2.3$ & $14.3 \pm 4.8$ & $14.1 \pm 1.6$ & $11.5 \pm 6.4$ & $17.2 \pm 5.5$ \\
\hline Available $\mathrm{P}^{* *}$ & $\left(\mathrm{mg} \mathrm{P} \mathrm{kg}^{-1}\right)$ & $14.0 \pm 2.1$ & $13.6 \pm 1.5$ & $6.3 \pm 1.0$ & $2.4 \pm 1.1$ & $5.5 \pm 1.2$ \\
\hline Al saturation & $(\%)$ & $62.9 \pm 5.1$ & $75.0 \pm 6.7$ & $50.4 \pm 4.4$ & $65.8 \pm 7.6$ & $44.5 \pm 13.6$ \\
\hline Clay $^{* *}$ & $(\%)$ & $29.0 \pm 8.8$ & $36.9 \pm 5.8$ & $41.2 \pm 7.2$ & $40.3 \pm 6.7$ & $45.9 \pm 1.9$ \\
\hline Silt $^{* *}$ & $(\%)$ & $21.8 \pm 5.9$ & $33.8 \pm 4.2$ & $5.1 \pm 2.7$ & $6.8 \pm 3.3$ & $6.4 \pm 2.1$ \\
\hline Sand & $(\%)$ & $49.1 \pm 11.9$ & $29.3 \pm 7.1$ & $53.7 \pm 7.4$ & $53.0 \pm 9.1$ & $47.7 \pm 2.6$ \\
\hline Bulk density & $\left(\mathrm{g} \mathrm{mL}^{-1}\right)$ & $1.08 \pm 0.07$ & $0.92 \pm 0.13$ & $1.01 \pm 0.09$ & $0.93 \pm 0.08$ & $0.90 \pm 0.04$ \\
\hline Particle density & $\left(\mathrm{g} \mathrm{mL}^{-1}\right)$ & $2.52 \pm 0.16$ & $2.49 \pm 0.15$ & $2.32 \pm 0.18$ & $2.83 \pm 0.65$ & $2.42 \pm 0.09$ \\
\hline Moisture content & $(\%)$ & $3.0 \pm 0.9$ & $4.4 \pm 0.5$ & $3.6 \pm 0.5$ & $4.0 \pm 0.7$ & $4.0 \pm 0.2$ \\
\hline
\end{tabular}

Values in the same row indicate means \pm standard deviation, ${ }^{\mathrm{a}} \mathrm{EC}$ : electrical conductivity, ${ }^{\mathrm{b}} \mathrm{SOM}$; soil organic matter, ${ }^{\mathrm{c}}$ Total C: total carbon; ${ }^{\mathrm{d}}$ Total N: total nitrogen; ${ }^{\mathrm{e}} \mathrm{CEC}$ : cation exchange capacity; ${ }^{\mathrm{f}}$ sum of exchangeable bases $\left(\mathrm{Ca}, \mathrm{Mg}, \mathrm{K}\right.$, and $\mathrm{Na}$ ); ${ }^{\mathrm{g}} \mathrm{ECEC}$; effective CEC, sum of exchangeable bases and exchangeable $\mathrm{Al} .{ }^{* * * *}$ Correlations are significant at $5 \%$ and $1 \%$ levels, respectively, among the rehabilitation sites.

(b)

\begin{tabular}{|c|c|c|c|c|c|c|}
\hline \multirow{2}{*}{\multicolumn{2}{|c|}{$\begin{array}{l}\text { Age-since-planting/Soil physicochemical } \\
\text { properties }\end{array}$}} & \multicolumn{4}{|c|}{ Rehabilitation sites } & \multirow{2}{*}{$\begin{array}{c}\text { Secondary fores } \\
\text { SF } \\
\text { (30 years) }\end{array}$} \\
\hline & & $\begin{array}{c}\text { SM96 } \\
\text { (18 years) }\end{array}$ & $\begin{array}{c}\text { SM97 } \\
\text { (17 years) }\end{array}$ & $\begin{array}{c}\text { SM98 } \\
\text { (16 years) }\end{array}$ & $\begin{array}{c}\text { SM99 } \\
\text { (15 years) }\end{array}$ & \\
\hline \multicolumn{7}{|c|}{ Subsurface soil, 30-40 cm depth } \\
\hline $\mathrm{pH}\left(\mathrm{H}_{2} \mathrm{O}\right)^{* *}$ & & $5.01 \pm 0.05$ & $5.04 \pm 0.05$ & $5.35 \pm 0.16$ & $5.29 \pm 0.05$ & $5.38 \pm 0.05$ \\
\hline $\mathrm{pH}(\mathrm{KCl})^{* *}$ & & $3.91 \pm 0.06$ & $3.72 \pm 0.04$ & $4.27 \pm 0.05$ & $4.33 \pm 0.06$ & $4.48 \pm 0.05$ \\
\hline $\mathrm{EC}^{\mathrm{a} * *}$ & $\left(\mu \mathrm{S} \mathrm{cm}^{-1}\right)$ & $52.7 \pm 7.0$ & $54.6 \pm 2.9$ & $47.5 \pm 7.9$ & $122.3 \pm 1.9$ & $132.9 \pm 13.3$ \\
\hline $\mathrm{SOM}^{\mathrm{b}}$ & $(\%)$ & $3.88 \pm 0.90$ & $4.03 \pm 0.74$ & $4.44 \pm 0.85$ & $4.70 \pm 0.84$ & $5.97 \pm 0.89$ \\
\hline Total $C^{c}$ & $\left(\mathrm{~g} \mathrm{~kg}^{-1}\right)$ & $22.6 \pm 5.2$ & $23.4 \pm 4.3$ & $25.8 \pm 4.9$ & $27.3 \pm 4.9$ & $34.6 \pm 5.1$ \\
\hline Total $\mathrm{N}^{\mathrm{d} *}$ & $\left(\mathrm{~g} \mathrm{~kg}^{-1}\right)$ & $0.95 \pm 0.44$ & $1.06 \pm 0.17$ & $1.07 \pm 0.29$ & $1.34 \pm 0.30$ & $1.61 \pm 0.41$ \\
\hline $\mathrm{C} / \mathrm{N}$ ratio & & $26.25 \pm 8.03$ & $22.10 \pm 3.40$ & $24.70 \pm 3.97$ & $20.62 \pm 3.28$ & $22.00 \pm 2.95$ \\
\hline $\mathrm{CEC}^{\mathrm{e}}$ & $\left(\mathrm{cmol}_{\mathrm{c}} \mathrm{kg}^{-1}\right)$ & $7.8 \pm 2.3$ & $7.3 \pm 1.4$ & $7.0 \pm 1.4$ & $7.7 \pm 1.7$ & $9.3 \pm 0.9$ \\
\hline Exch. $\mathrm{Ca}^{2+}$ & $\left(\mathrm{cmol}_{\mathrm{c}} \mathrm{kg}^{-1}\right)$ & $0.13 \pm 0.05$ & $0.17 \pm 0.07$ & $0.43 \pm 0.19$ & $0.02 \pm 0.02$ & $0.07 \pm 0.05$ \\
\hline Exch. $\mathrm{Mg}^{2+}$ & $\left(\mathrm{cmol}_{\mathrm{c}} \mathrm{kg}^{-1}\right)$ & $0.12 \pm 0.04$ & $0.15 \pm 0.10$ & $0.11 \pm 0.07$ & $0.11 \pm 0.01$ & $0.14 \pm 0.07$ \\
\hline Exch. $\mathrm{K}^{+* *}$ & $\left(\mathrm{cmol}_{\mathrm{c}} \mathrm{kg}^{-1}\right)$ & $0.06 \pm 0.02$ & $0.06 \pm 0.01$ & $0.08 \pm 0.02$ & $0.11 \pm 0.02$ & $0.25 \pm 0.06$ \\
\hline Exch. $\mathrm{Al}^{3+* *}$ & $\left(\mathrm{cmol}_{\mathrm{c}} \mathrm{kg}^{-1}\right)$ & $2.72 \pm 1.18$ & $4.30 \pm 0.66$ & $1.30 \pm 0.30$ & $1.56 \pm 0.17$ & $1.81 \pm 0.23$ \\
\hline
\end{tabular}


(b) Continued.

\begin{tabular}{|c|c|c|c|c|c|c|}
\hline \multirow{2}{*}{\multicolumn{2}{|c|}{$\begin{array}{l}\text { Age-since-planting/Soil physicochemical } \\
\text { properties }\end{array}$}} & \multicolumn{4}{|c|}{ Rehabilitation sites } & \multirow{3}{*}{$\begin{array}{c}\text { Secondary forest } \\
\text { SF } \\
\text { (30 years) } \\
0.89 \pm 0.30\end{array}$} \\
\hline & & \multirow{2}{*}{$\begin{array}{c}\begin{array}{c}\text { SM96 } \\
\text { (18 years) }\end{array} \\
0.65 \pm 0.19\end{array}$} & \multirow{2}{*}{$\begin{array}{c}\text { SM97 } \\
\text { (17 years) }\end{array}$} & \multirow{2}{*}{$\begin{array}{c}\text { SM98 } \\
\text { (16 years) }\end{array}$} & \multirow{2}{*}{$\begin{array}{c}\text { SM99 } \\
\text { (15 years) } \\
0.32 \pm 0.04\end{array}$} & \\
\hline SUM $^{f}$ & $\left(\mathrm{cmol}_{\mathrm{c}} \mathrm{kg}^{-1}\right)$ & & & & & \\
\hline $\mathrm{ECEC}^{\mathrm{g} * *}$ & $\left(\mathrm{cmol}_{\mathrm{c}} \mathrm{kg}^{-1}\right)$ & $3.37 \pm 1.33$ & $5.06 \pm 0.76$ & $2.16 \pm 0.44$ & $1.88 \pm 0.16$ & $2.69 \pm 0.38$ \\
\hline Base saturation & (\%) & $8.6 \pm 2.4$ & $10.4 \pm 1.5$ & $12.6 \pm 4.1$ & $4.3 \pm 0.9$ & $9.5 \pm 3.0$ \\
\hline Available $\mathrm{P}^{* *}$ & $\left(\mathrm{mg} \mathrm{P} \mathrm{kg}{ }^{-1}\right)$ & $5.9 \pm 1.5$ & $3.7 \pm 0.4$ & $2.6 \pm 1.3$ & $3.3 \pm 1.9$ & $0.9 \pm 0.3$ \\
\hline $\mathrm{Al}$ saturation & (\%) & $79.0 \pm 7.6$ & $85.0 \pm 2.3$ & $60.5 \pm 9.4$ & $82.9 \pm 3.0$ & $67.6 \pm 8.9$ \\
\hline Clay & (\%) & $31.2 \pm 6.9$ & $37.7 \pm 6.4$ & $36.1 \pm 8.6$ & $36.5 \pm 5.8$ & $48.1 \pm 2.5$ \\
\hline Silt $^{* *}$ & (\%) & $25.8 \pm 5.8$ & $30.9 \pm 2.8$ & $8.7 \pm 7.5$ & $8.7 \pm 3.5$ & $4.9 \pm 1.1$ \\
\hline Sand $^{* *}$ & (\%) & $43.0 \pm 7.0$ & $31.4 \pm 8.7$ & $55.2 \pm 13.2$ & $54.9 \pm 3.8$ & $47.0 \pm 2.9$ \\
\hline Bulk density & $\left(\mathrm{g} \mathrm{mL}^{-1}\right)$ & $1.32 \pm 0.14$ & $1.11 \pm 0.04$ & $1.36 \pm 0.12$ & $1.35 \pm 0.18$ & $1.13 \pm 0.19$ \\
\hline Particle density & $\left(\mathrm{g} \mathrm{mL}^{-1}\right)$ & $2.50 \pm 0.15$ & $2.53 \pm 0.09$ & $2.40 \pm 0.14$ & $2.68 \pm 0.14$ & $2.62 \pm 0.27$ \\
\hline Moisture content & (\%) & $2.6 \pm 0.9$ & $3.7 \pm 0.7$ & $2.8 \pm 0.6$ & $3.3 \pm 0.7$ & $3.7 \pm 0.4$ \\
\hline
\end{tabular}

Values in the same row indicate means \pm standard deviation, ${ }^{a} \mathrm{EC}$ : electrical conductivity, ${ }^{\mathrm{b}} \mathrm{SOM}$; soil organic matter, ${ }^{\mathrm{c}}$ Total C: total carbon; ${ }^{\mathrm{d}}$ Total N: total nitrogen; ${ }^{\mathrm{e}} \mathrm{CEC}$ : cation exchange capacity; ${ }^{\mathrm{f}}$ sum of exchangeable bases (Ca, $\mathrm{Mg}, \mathrm{K}$, and $\left.\mathrm{Na}\right) ;{ }^{\mathrm{g}} \mathrm{ECEC}$; effective CEC, sum of exchangeable bases and exchangeable $\mathrm{Al} .{ }^{* * * *}$ Correlations are significant at $5 \%$ and $1 \%$ levels, respectively, among the rehabilitation sites.

3.2. Soil Texture, Organic Matter, and Cation Exchange Capacity-Related Properties. The fertility of tropical soils is mainly dependent on the negative charges derived from clay content and organic matter under the acidic nature of the soils [46-48]. In the present study, a high positive correlation was observed between Total $\mathrm{C}$ and clay contents in both the surface soils and subsurface soils: $r=0.832^{* *}$ and $r=0.880^{* *}$ (data not shown), respectively. This indicated that they are ascribable to soil organic matter stabilization by the stable organomineral complexes formation $[48,49]$. However, the results of standardized multiple regression analysis showed no correlation between CEC values and either Total $\mathrm{C}$ or clay contents in either surface $(\mathrm{CEC}=0.211$ Total C -0.057 clay $(r=0.167)$ ) or subsurface soils (CEC $=0.504$ Total $\mathrm{C}+0.199$ clay $(r=0.686))$. The fact that the $\mathrm{CEC}$ was higher as compared to the effective cation exchange capacity (ECEC) suggested the possible existence of certain variable negative charges $[47,50]$. Since the ECEC values were much lower than the CEC values, permanent negative charges of clay minerals were predominant under acidic conditions. The small difference between soil CEC and ECEC suggested low input of negative charges from soil organic matter to the cation retention capacity [21]. Although the content of soil total carbon was significantly higher in secondary forest than rehabilitation sites, there was no large difference between the rehabilitation sites and secondary forest for soil total carbon, total nitrogen, or clay contents. It is notable that the negative charges derived from clay content and organic matter are considered as a significant factor for nutrient retention capacity and possibly influence the fertility status of soils to a certain extent [23]. In addition, the soil Total C, Total N, and CEC values are also likely to be affected by the input-output balance of soil organic matter after the period of establishment of the rehabilitation sites and in the fallow period of the secondary forest, through inputs of litterfall and output by decomposition.
According to Akbar et al. [51], organic matter from the soil gradually decreased after harvesting or clearing of forest due to the loss of organic matter source from the plant. Nevertheless, similar studies by Nye and Greenland [52], Kendawang et al. [16], and Ilstedt et al. [7] mentioned that the soil organic matter decreases rapidly after the soil was exposed to land clearing or harvesting activities. A study by Ishizuka et al. [53] reported that the soil organic matter content was high in the surface layers due to the accumulation of forest litter and the development of root mats in the soil. Similar findings revealed in the present study whereby the soil organic matter values in surface soils were generally higher as compared to the subsurface soils. The higher content of soil Total C especially in the secondary forest was likely due to a large input and greater accumulation of fresh organic matter in soils from the existing vegetation in the former than the latter.

\subsection{Soil Acidity and Exchangeable Bases-Related Properties.} According to Juo and Manu [54], the loss of soil exchangeable bases via uptake by vegetation and leaching in the tropical environment as well as volatilization during combustion had caused soils being acidic in nature, especially in the reforestation sites [55]. In addition, Tan [44] reported that, for soil $\mathrm{pH}$ below 6.0, some available nutrients are poor. The formation of clay minerals and microbial activity including soil characteristics and processes are influenced by the soil $\mathrm{pH}$. In the present study, especially in SM96 and SM97 rehabilitation sites, the soil $\mathrm{pH}$ for both surface and subsurface soils was more acidic as compared to the secondary forest due to the occurrence of high soil exchangeable Al. The presence of a large amount of aluminium and hydrogen ions in the soils resulted in the acidity of forest soils. In addition, Zaidey et al. [15] stated that the soil organic matter content and $\mathrm{Al}$ concentrations probably contributed to the soil acidity. Although aluminium is not useful for plant growth and not deliberated as a plant nutrient, it could be used as an indicator 
for weathering status and acidity of the soils. Akbar et al. [51] mentioned that Al toxicity will disturb and restrict the growth of seedling and the acidity presumably caused by water deficiency during drought season. Accumulation of forest litter and development of root mats on the surface layer of soil may result in high carbon content, which may indirectly affect the acidity of the soil.

Nonetheless, Etsuko et al. [56] reported that higher amount of calcium corresponds to the higher $\mathrm{pH}$ value. Association of biological accumulation through the supply of forest litter and their lower mobility in soil caused higher contents of soil exchangeable $\mathrm{Ca}$ and $\mathrm{Mg}$ in surface soils $[57,58]$. During heavy rainfall season, the exchangeable $\mathrm{K}$ from the decomposition of dead plants probably dissolved easily into the deep layer of soil. In addition, Ohta and Effendi [59] described that subsurface soil may play a vital role as a nutrient storage whereby some available nutrients in the subsurface layer are pumped up and transferred gradually to the surface soil.

3.4. Identification of Intrinsic Soil Properties in relation to Soil Fertility at Rehabilitation Sites. Principal Component Analysis (PCA) is a multivariate data analysis used to analyze set of soil physicochemical properties to reduce the original complicated dimensionality and to give a few principal components (PC score) that explain the variation in the data [21]. In the present study, PCA was computed and performed for the rehabilitated sites (SM96, SM97, SM98, and SM99) by using thirteen selected variables related to the surface and subsurface soil physicochemical properties in order to determine the important variables that affect the soil fertility at the study sites as shown in Table 3.

The PCA results generated three most significant PC scores (PC1, PC2, and PC3), which described approximately $76.3 \%$ of the total variability and each component portrays a series of variables which simplifies the analysis and interpretation. The first component score (PC1) represents intrinsic properties of the soil related to phosphorus, soil acidity, and soil texture, such as exchangeable $\mathrm{Al}$, available phosphorus, and silt content which exhibited high positive factor loadings, while $\mathrm{pH}\left(\mathrm{H}_{2} \mathrm{O}\right)$ and sand content exhibited high negative factor loadings for surface soils. The second principal component (PC2) showed a high positive factor loading for total nitrogen, clay content, and soil organic matter, whereas a high negative factor loading for bulk density reflects soil organic matter constituent at surface soils. Meanwhile, at subsurface soils, the first principal component (PC1) was related to soil acidity and soil texture as exchangeable $\mathrm{Al}$ and silt content showed high positive factor loadings, while $\mathrm{pH}\left(\mathrm{H}_{2} \mathrm{O}\right)$, sand content, and bulk density showed high negative factor loadings (Table 3). On the other hand, PC2 for subsurface soils showed a high positive factor loading for total nitrogen, exchangeable $\mathrm{K}$, clay content, and bulk density reflecting the cation retention capacity and soil organic matter constituent. The third principal component (PC3) at subsurface soils was related to available nutrient as exchangeable Ca showed a high negative factor loading. Thus, based on the results obtained, this indicated that the PCA produces the ability of the three principal component scores to integrate soil physicochemical characteristics within the components. In addition, the information derived from PCA can be applied to the development of basic indicators which can be used to explain the more complex variability of soil physicochemical properties. Based on PCA, since subsurface soil properties showed similar but fewer tendencies than those of the surface soils, the intrinsic results of surface soils properties will be chiefly used for further discussion. The first component score, PC1 from PCA, will be used for the discussion since it shows the highest contribution ratio (34.4\%) as compared to PC2 (29.2\%) and PC3 (12.7\%).

3.5. Relationship between Soil Fertility and Growth Performance of Planted Shorea macrophylla (de Vriese) at DifferentAge Stands with Special Reference to PC Score, SFI, and SEF. The suitable procedure to assess the soil conditions in the tropical rainforests was found difficult due to the variations of soil properties. In forest management, the evaluation of soil fertility status and site quality is essential since it reflects the productive capacity of the forest area to support the growth of plants [21, 30]. Moran et al. [29] stated that a Soil Fertility Index (SFI) was employed to investigate the relationship between soil fertility and secondary forests succession rate as well as vegetation selection, while the Soil Evaluation Factor (SEF) was used to evaluate soil fertility with different soil types [30]. Originally, the Soil Fertility Index (SFI) was developed as a measure of fertility of soils for cacao production [60]. In the Amazonian humid tropical forests of Brazil, both of these soil indices were used to predict the increase in aboveground biomass and to evaluate soil fertility and site productivity under various stages of tropical secondary forests succession. Furthermore, in Northern Thailand, studies have proven that SFI and SEF have been used for soil quality and productivity along a gradient of land degradation [12]. However, less attention has been paid to the applicability of using these soil indices for estimating soil fertility and site quality in secondary forests undergoing rehabilitation especially by using indigenous species [21] (Dipterocarp species such as Shorea macrophylla), as for the case in this study. To investigate if any proposed index for estimating soil quality is applicable to the soils in Sampadi Forest Reserve as well as for the association between the soil fertility status and productivity of planted Shorea macrophylla (de Vriese) after enrichment planting, correlations between the PCA score and the values of Soil Fertility Index (SFI) [29] and Soil Evaluation Factor (SEF) [30] were developed.

Thus, the SFI and SEF were proposed for the rehabilitation sites in the present study since both indices are applicable for estimating soil fertility under vegetation succession of secondary forest in humid tropical regions of Brazil $[29,30]$. A principal component analysis showed the most important PC scores and revealed the significant soil properties which contribute to the soil fertility under rehabilitation (Table 3). The values of Soil Fertility Index (SFI) and Soil Evaluation Factor (SEF) for rehabilitation sites and secondary forest (SF) for surface soils $(0-10 \mathrm{~cm})$ and subsurface soils $(30-40 \mathrm{~cm})$ were clearly explained in our previous study [28, 45]. The relationship between PC1 score and SFI and between the PC1 score and the SEF is shown in Figure 2. Based on Figure 2, 
TABLE 3: Factor loadings of surface and subsurface soil physicochemical properties, principal component analysis (PCA), and results of PCA of the rehabilitated forest.

\section{Variables analyzed}

pH $\left(\mathrm{H}_{2} \mathrm{O}\right)$, SOM, Total N, CEC, Exch. Ca, Exch. Mg, Exch. K, Exch. Al, Available P, clay, silt, sand contents, and bulk density

Value PC1 PC2 PC3

Surface soils $(0-10 \mathrm{~cm})$

Contribution ratio (\%)

34.4

29.2

12.7

Variables with a high positive factor loading $(>0.7)$

Exch. Al, Available P, and silt

Total N, clay, and SOM

ND

Variables with a high negative factor loading $(>0.7)$

$\mathrm{pH}\left(\mathrm{H}_{2} \mathrm{O}\right)$ and sand

Bulk density

ND

Contribution name of $\mathrm{PC}$ axis

Available phosphorus, soil acidity, and soil

Soil organic matter constituent

Subsurface soils $(30-40 \mathrm{~cm})$

Contribution ratio (\%)

Variables with a high positive factor loading $(>0.7)$

Variables with a high negative factor loading $(>0.7)$

Contribution name of $\mathrm{PC}$ axis

$$
\text { texture }
$$

34.4

Exch. $\mathrm{Al}$ and silt

$\mathrm{pH}\left(\mathrm{H}_{2} \mathrm{O}\right)$, sand, and bulk density

Soil acidity and soil texture
29.3

Total N, Exch. K, clay, and SOM

$\mathrm{ND}$

ND

Exch. Ca

Cation retention capacity, soil organic matter constituent

$(+)$ = factor loading with a positive value; $(-)=$ factor loading with a negative value; and $\mathrm{ND}=$ not determined. $\mathrm{SOM}=$ soil organic matter, Total $\mathrm{N}=$ total nitrogen, Exch. $\mathrm{Ca}, \mathrm{Mg}, \mathrm{K}$, and $\mathrm{Al}=$ exchangeable $\mathrm{Ca}, \mathrm{Mg}, \mathrm{K}$, and $\mathrm{Al}$, clay, silt, and sand = percentage of clay, silt, and sand.
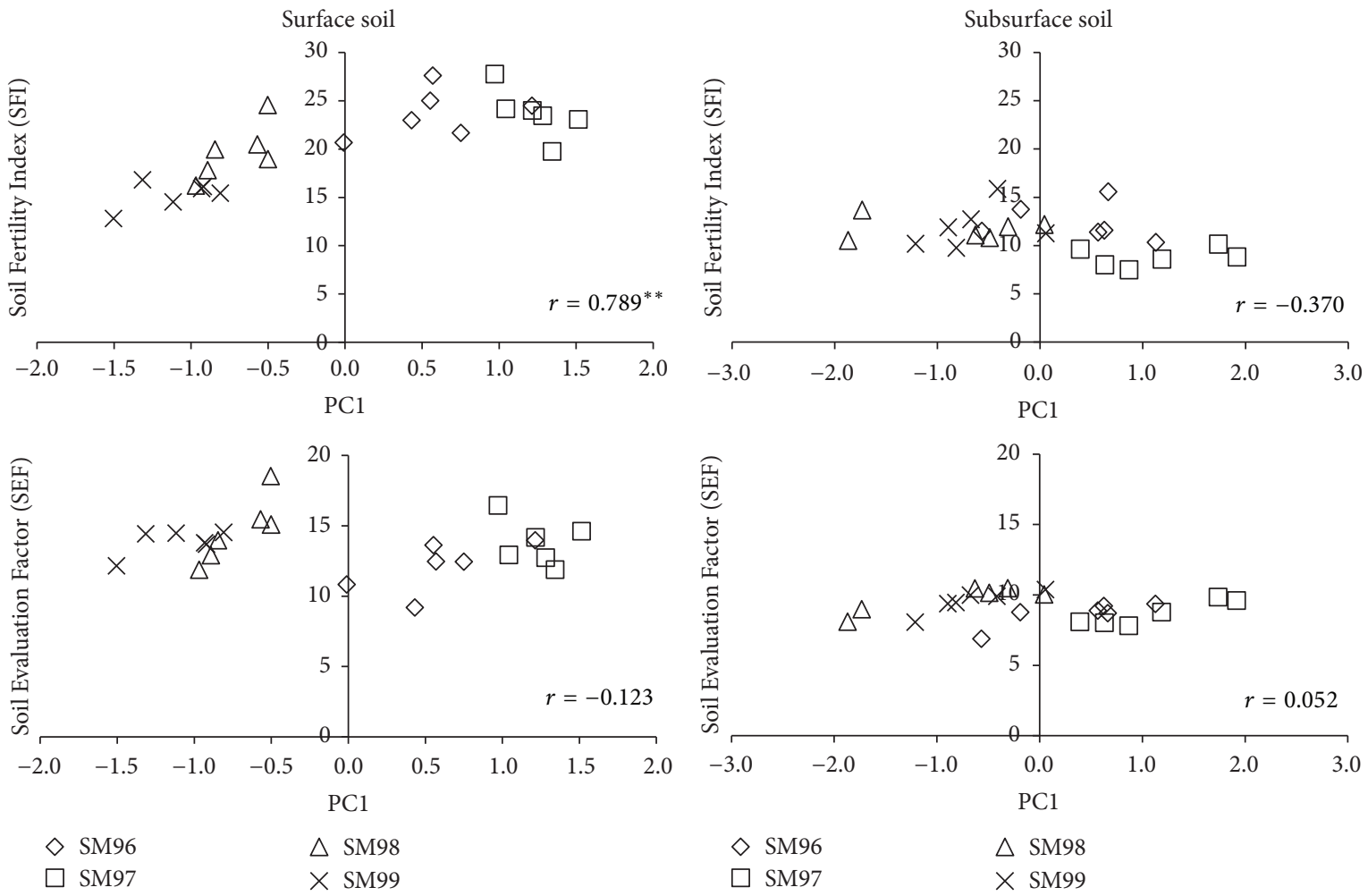

FIgURE 2: Relationship between PC1 score derived from PCA analysis and the calculated Soil Fertility Index (SFI) and Soil Evaluation Factor (SEF) for surface and subsurface soils. ${ }^{* *}$ Correlations are significant at $1 \%$ level, using Pearson correlation matrix. 

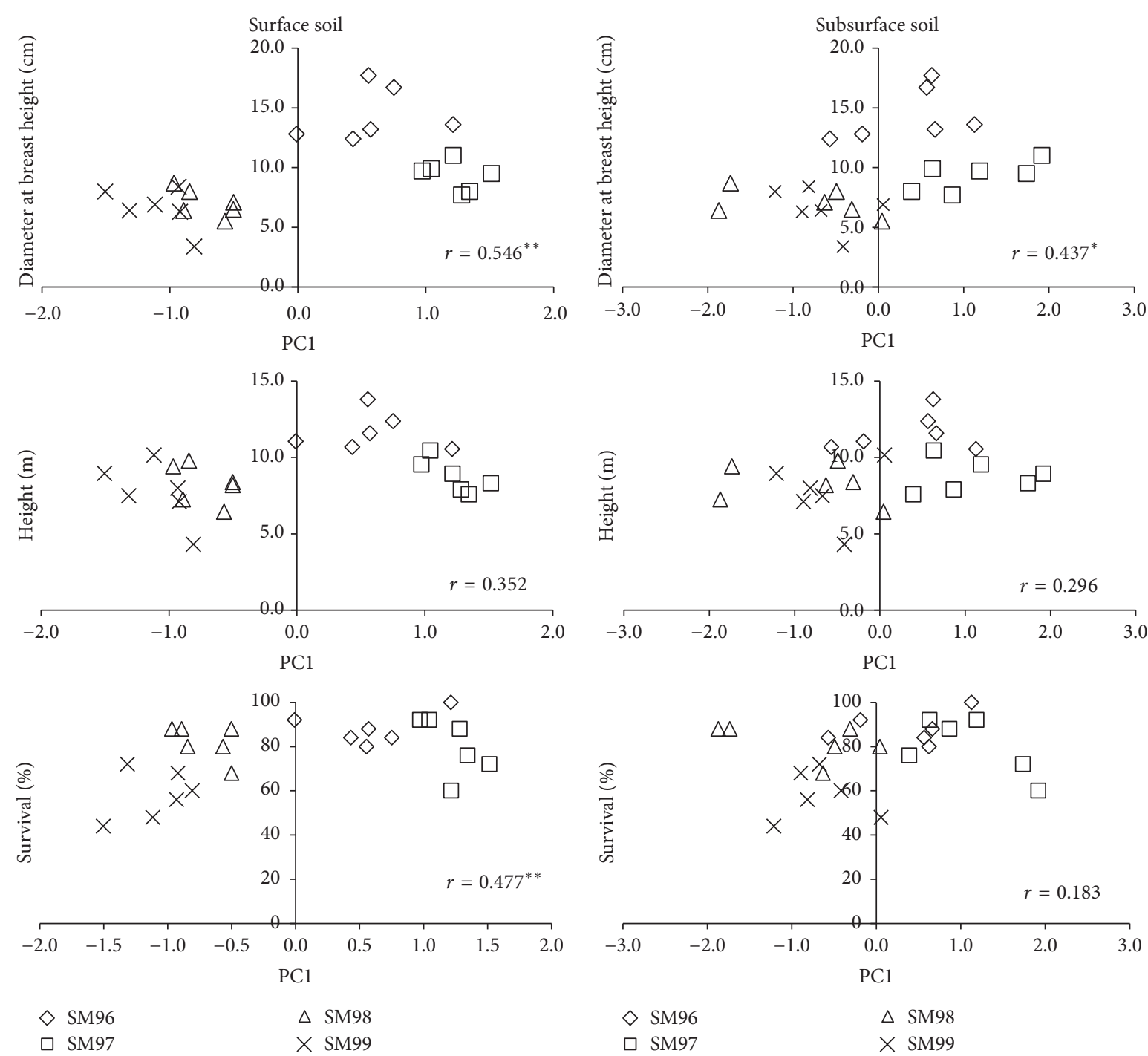

FIGURE 3: Relationship between PCl score, diameter at breast height (DBH), height, and percentage of survival derived from surface and subsurface soils. ${ }^{* * *}$ Correlations are significant at $5 \%$ and $1 \%$ levels, respectively, using Pearson correlation matrix.

there was a high positive correlation between the PC1 score and SFI at surface soils $\left(r=0.789^{* *}, P<0.01\right)$ but no correlation was found at subsurface soils. On the other hand, no correlation was found between the PC1 score and SEF for both surface and subsurface soils. Hence, the results revealed that SFI showed similarity factors with the PC1 score, indicating the applicability of SFI as an index which can be used for estimating soil fertility status in the present study.

Nonetheless, in order to determine the applicability of these indices for estimating soil fertility and site quality in relation to survivorship and growth performance of planted Shorea macrophylla after enrichment planting, the values of the PC1 score, SFI, and SEF at both surface and subsurface soil depths were further correlated with the tree growth parameters (diameter at breast height (DBH) and height) and survival of the planted Shorea macrophylla trees from our previous study [18]. The results revealed positive and moderate correlations between the PC1 score and diameter at breast height $(\mathrm{DBH})$ and survival percentage at surface soils $\left(r=0.546^{* *}, P<0.01\right.$ and $r=0.477^{*}, P<0.05$, resp.) as shown in Figure 3. On the other hand, there was no correlation observed between PC1 score and the tree height of $S$. macrophylla at both surface and subsurface soils. Meanwhile, at subsurface soils, there was a positive correlation obtained between PC1 score and diameter at breast height $\left(r=0.437^{*}, P<0.05\right)$. However, no correlation was found between the PC1 score and the survival percentage of the trees at subsurface soils (Figure 3). Based on Table 4, the results indicated that there were high correlations between SFI and DBH, height, and percentage of survival at surface soils. The correlation coefficient between the SFI and DBH, height, and percentage of survival ranged from 0.483 to 0.684 . The SFI was correlated with DBH $\left(r=0.565^{* *}, P<0.01\right)$, height $\left(r=0.483^{*}, P<0.05\right)$, and survival $\left(r=0.684^{* *}, P<\right.$ $0.01)$ at surface soils, whereas no significant correlations were found at subsurface soils for SFI (Figure 4). Moreover, there 

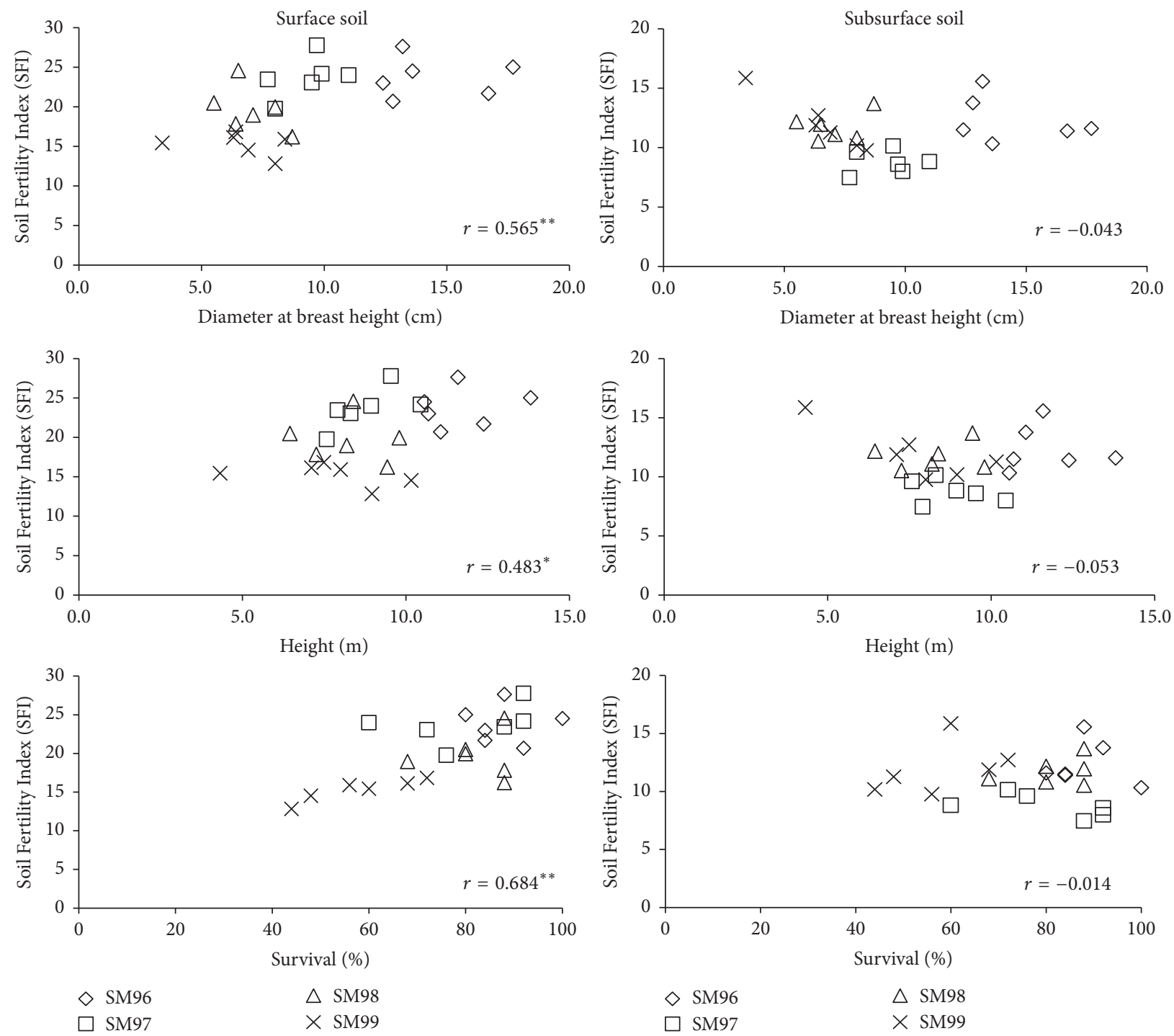

FIGURE 4: Relationship between diameter at breast height (DBH), height, and percentage of survival with Soil Fertility Index (SFI) derived from surface and subsurface soils. ${ }^{* * *}$ Correlations are significant at $5 \%$ and $1 \%$ levels, respectively, using Pearson correlation matrix.

were no significant correlations observed between SEF and $\mathrm{DBH}$, height, and survival percentage for both surface and subsurface soils as shown in Figure 5. Hence, these results showed that the SFI is also one of the applicable indices to determine soil fertility status as well as site quality in relation to the productivity of Shorea macrophylla planting in this study. Arifin et al. [21] mentioned that SEF might not be appropriate for sandy texture soils such as in the present study since the level of soil exchangeable cations was relatively lower than that of soil exchangeable Al. A brief summary of the relationship between $\mathrm{PC1}$ score, SFI, SEF, and tree growth parameters (diameter at breast height (DBH) and height) and percentage of survival was shown in Table 4.

Notwithstanding, to predict the best indicator for estimating soil fertility and site quality in relation to survivorship and growth performance of planted Shorea macrophylla after enrichment planting, the values of soil available phosphorus content at the rehabilitation sites at both surface and subsurface soil depths were correlated with tree growth parameters (diameter at breast height (DBH) and height) and survival from our previous study [18]. The results indicated that there was a strong relationship between the soil available phosphorus and tree growth parameters: diameter at breast height, height, and percentage of survival as shown in Figure 6 . There were strong and moderate positive correlations between the soil available phosphorus and diameter at breast height at surface soils $\left(r=0.678^{* *}, P<0.01\right)$ and subsurface soils $\left(r=0.454^{*}, P<0.05\right)$, respectively. Nonetheless, a positive correlation was also observed between soil available phosphorus and the height and survival percentage at surface soils $\left(r=0.551^{* *}\right.$ and $r=0.676^{* *}, P<0.01$, resp.). Based on Figure 6, the soil available phosphorus is directly proportional to the diameter at breast height, tree height, and survival percentage of the planted S. macrophylla in 

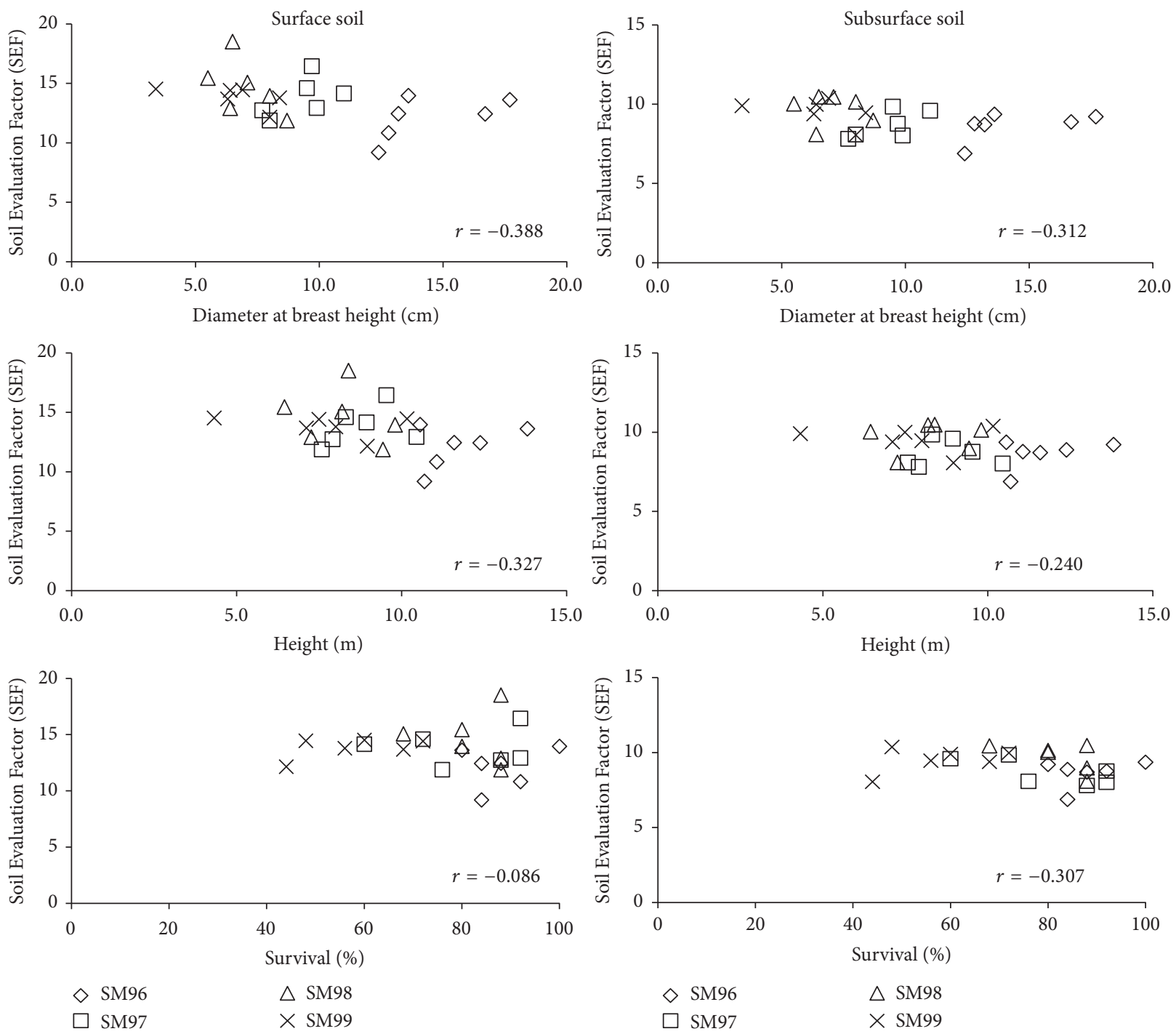

FIGURE 5: Relationship between diameter at breast height (DBH), height, and percentage of survival with Soil Evaluation Factor (SEF) derived from surface and subsurface soils.

TABLE 4: Summary of the relationship between PC1 score, SFI, SEF, and tree growth parameters (diameter at breast height (DBH), height, and percentage of survival).

\begin{tabular}{|c|c|c|c|c|c|c|}
\hline \multirow{2}{*}{$\begin{array}{l}\text { Growth } \\
\text { parameters }\end{array}$} & \multicolumn{2}{|c|}{$\mathrm{PC1}$} & \multicolumn{2}{|c|}{ SFI } & \multicolumn{2}{|c|}{ SEF } \\
\hline & Surface $(0-10 \mathrm{~cm})$ & $\begin{array}{l}\text { Subsurface } \\
(30-40 \mathrm{~cm})\end{array}$ & Surface $(0-10 \mathrm{~cm})$ & $\begin{array}{l}\text { Subsurface } \\
(30-40 \mathrm{~cm})\end{array}$ & Surface $(0-10 \mathrm{~cm})$ & $\begin{array}{l}\text { Subsurface } \\
(30-40 \mathrm{~cm})\end{array}$ \\
\hline $\mathrm{DBH}$ & $0.546^{* *}$ & $0.437^{*}$ & $0.565^{* *}$ & -0.043 & -0.388 & -0.312 \\
\hline Height & 0.352 & 0.296 & $0.483^{*}$ & -0.053 & -0.327 & -0.240 \\
\hline Survival & $0.477^{*}$ & 0.183 & $0.684^{* *}$ & -0.014 & -0.086 & -0.307 \\
\hline
\end{tabular}

${ }^{*, * *}$ Correlations are significant at $5 \%$ and $1 \%$ levels, respectively, using Pearson correlation matrix.

the rehabilitation sites. Consequently, based on the results of correlation at surface soils, it can be deduced that soil available phosphorus (DBH: $r=0.678^{* *}, P<0.01$; height: $\left.r=0.551^{* *}, P<0.01\right)$ is clearly a better indicator of $S$. macrophylla productivity than the SFI (DBH: $r=0.565^{* *}, P$ $<0.01$; and height: $\left.r=0.483^{*}, P<0.05\right)$ in the present study.
According to our previous study [18, 19], high content of available phosphorus in soils was related to an increase in the growth and survival percentage of $S$. macrophylla in SM96 and SM97, whereas the low content of available phosphorus was related to a decrease in the growth and survival percentage of the planted trees in the SM98 and 

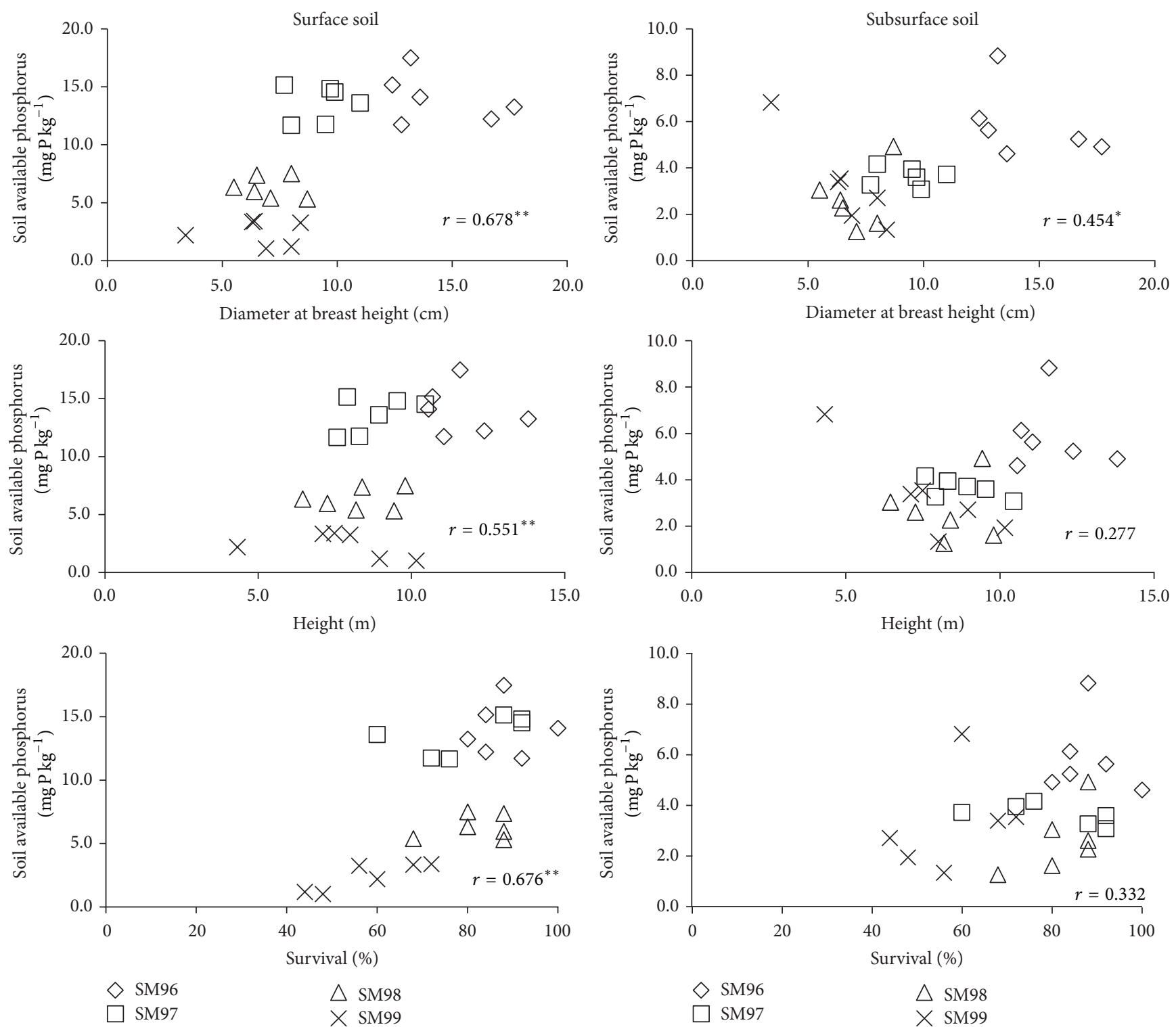

FIGURE 6: Relationship between soil available phosphorus with diameter at breast height (DBH), height, and percentage of survival derived from surface and subsurface soils. ${ }^{*, * *}$ Correlations are significant at $5 \%$ and $1 \%$ levels, respectively, using Pearson correlation matrix.

SM99 sites. One possible reason for the poor growth rate of the planted S. macrophylla (data not shown) especially in study sites SM98 and SM99 was probably due to the low availability of soil phosphorus pools in the form of organic and inorganic phosphorus in the bulk soil, which would limit the uptake of plants. Phosphorus is transported principally by diffusion, whereas soluble minerals such as potassium, K, are transferred via the soil through bulk flow and diffusion. High plant uptake rates create a zone around the root which is depleted of $\mathrm{P}$ since the rate of $\mathrm{P}$ diffusion is slow [61]. According to Perrott et al. [62] and Frossard et al. [63], the content of soil available P largely depends on a combination of factors including the uptake of plant, adsorption-desorption, and dissolution-precipitation of inorganic $\mathrm{P}$, organic $\mathrm{P}$ mineralization, microbial immobilization, and addition of fertilizer. Immobile forms of $\mathrm{P}$ to the soil solution were released by soil microbes and the microbes are responsible for the $\mathrm{P}$ immobilization [61]. Likewise, a study conducted in unimproved grassland and 19-year-old stand by Chen et al. [64] concluded that the recycling of $\mathrm{P}$ was largely driven by plant $\mathrm{P}$ demand and sustained by leaf litter inputs and root in forest ecosystems. Environmental factors such as the amount of rainfall, soil temperature, and moisture might also influence the availability of $\mathrm{P}$.

\section{Conclusions and Recommendations}

In conclusion, the assessment on the status of soil physicochemical properties showed that the soil properties are significantly varied between the rehabilitation sites (SM96, 
SM97, SM98, and SM99) and secondary forest (SF). Generally, the soils in rehabilitation sites and secondary forest of Sampadi Forest Reserve could be categorized as strongly acidic in nature, $\mathrm{pH}\left(\mathrm{H}_{2} \mathrm{O}\right)$ values of less than 5.50 with poor soil exchangeable bases, and low nutrient status at surface and subsurface soil layers. The soils were relatively sandy, ranging from sandy clay loam to sandy clay in texture. Soil total carbon and total nitrogen in the secondary forest were significantly higher than those of the rehabilitation sites, showing that a large pool of fresh organic matter was derived from the above vegetation in the surface and subsurface soils. Principal Component Analysis (PCA) generated three most significant components which explained about $76.3 \%$ of the total variability and each component portrays a series of variables which simplifies the analysis and interpretation. The first component score (PC1) represents phosphorus content, soil acidity, and soil texture. Soil organic matter constituent and cation retention capacity represent PC2, whereas available nutrient represents PC3. Pearson correlation analysis indicated that Soil Fertility Index (SFI) was highly correlated with $\mathrm{PCl}$ score, diameter at breast height (DBH), height, and survival of the planted Shorea macrophylla trees at surface soils, indicating the applicability of SFI as an index to estimate and quantify soil fertility and site quality under line planting technique in the present study. For practical purposes, it can be deduced that the SFI can be used as an index to assess the difference in growth of planted trees caused by variability and heterogeneity of soil fertility levels of degraded forestland within a site. Notwithstanding, the results also showed that there was a strong association between soil available phosphorus with tree growth parameters indicating that soil available phosphorus is a better indicator than SFI in the present study. Consequently, it is recommended that, in future, further comprehensive studies on other environmental factors including soil biological properties which might influence the tree growth performance should be implemented. In addition, early establishment of experimental reforestation at nursery and field trials should be undertaken in order to obtain the initial data on seedling growth performance prior to outplanting.

\section{Disclosure}

The research project was conducted under the supervision of Dr. Mohd Effendi Wasli and the project was run as Mugunthan Perumal's research project.

\section{Conflicts of Interest}

The authors declare that there are no conflicts of interest regarding the publication of this paper.

\section{Acknowledgments}

This research was financially supported by the research grant from Fundamental Research Grant Scheme (FRGS) (E14099/F07/69/989/2013(30)) from Ministry of Higher Education, Malaysia, and a Universiti Malaysia Sarawak (UNIMAS) internal grant under the Ph.D. Student Fund
(F07/DPP56/1353/2016/3), Grant-in-Aid for scientific research purpose by the Japan-Malaysia Association (JMA), and NPO Rainforest Sarawak. The authors wish to express gratitude to the Director and staff of the Forest Department, Sarawak, for their supportive assistance during the duration of this study. The authors would also like to extend thanks to local villagers from the study area for their kind cooperation and assistance during the field survey.

\section{References}

[1] P. Panwar, S. Pal, S. K. Reza, and B. Sharma, "Soil fertility index, soil evaluation factor, and microbial indices under different land uses in acidic soil of humid subtropical India," Communications in Soil Science and Plant Analysis, vol. 42, no. 22, pp. 2724-2737, 2011.

[2] ITTO, Guidelines for the Restoration, Management and Rehabilitation of Degraded and Secondary Tropical Forests, Policy Development Series 13, ITTO, Yokohama, Japan, 2002.

[3] J. Ramos and S. del Amo, "Enrichment planting in a tropical secondary forest in Veracruz, Mexico," Forest Ecology and Management, vol. 54, no. 1-4, pp. 289-304, 1992.

[4] G. Ådjers, S. Hadengganan, J. Kuusipalo, K. Nuryanto, and L. Vesa, "Enrichment planting of dipterocarps in logged-over secondary forests: effect of width, direction and maintenance method of planting line on selected Shorea species," Forest Ecology and Management, vol. 73, no. 1-3, pp. 259-270, 1995.

[5] R. Otsamo, "Effect of nurse tree species on early growth of Anisoptera marginata Korth. (Dipterocarpaceae) on an Imperata cylindrica (L.) Beauv dominated grasslands site in South Kalimantan, Indonesia," Forest Ecology and Management, vol. 105, no. 1-3, pp. 303-311, 1998.

[6] A. Vincent and S. J. Davies, "Effects of nutrient addition, mulching and planting-hole size on early performance of Dryobalanops aromatica and Shorea parvifolia planted in secondary forest in Sarawak, Malaysia," Forest Ecology and Management, vol. 180, no. 1-3, pp. 261-271, 2003.

[7] U. Ilstedt, A. Malmer, A. Nordgren, and P. Liau, "Soil rehabilitation following tractor logging: early results on amendments and tilling in a second rotation Acacia mangium plantation in Sabah, Malaysia," Forest Ecology and Management, vol. 194, no. 1-3, pp. 215-222, 2004.

[8] A. E. Lugo, "The apparent paradox of reestablishing species richness on degraded lands with tree monocultures," Forest Ecology and Management, vol. 99, no. 1-2, pp. 9-19, 1997.

[9] J. A. Parrotta, J. W. Turnbull, and N. Jones, "Catalyzing native forest regeneration on degraded tropical lands," Forest Ecology and Management, vol. 99, no. 1-2, pp. 1-7, 1997.

[10] M. E. McDill and R. L. Amateis, "Tree growth in primary lowland and hill dipterocarp forests," Journal of Tropical Forest Science, vol. 6, pp. 332-345, 1992.

[11] J. C. Onyekwelu, "Site index curves for site quality assessment of Nauclea diderrichii monoculture plantations in Omo Forest Reserve, Nigeria," Journal of Tropical Forest Science, vol. 17, no. 4, pp. 532-542, 2005.

[12] R. Doi and K. Sakurai, "Principal components derived from soil physicochemical data explained a land degradation gradient, and suggested the applicability of new indexes for estimation of soil productivity in the Sakaerat Environmental Research Station, Thailand," International Journal of Sustainable Development \& World Ecology, vol. 11, no. 3, pp. 298-311, 2004. 
[13] G. Ådjers, J. Kuusipalo, S. Hadengganan, K. Nuryanto, and L. Vesa, "Performance of ten dipterocarp species in restocking logged-over forest areas subjected to shifting cultivation," Journal of Tropical Forest Science, vol. 9, no. 2, pp. 151-160, 1996.

[14] F. Montagnini, B. Eibl, L. Grance, D. Maiocco, and D. Nozzi, "Enrichment planting in overexploited subtropical forests of the Paranaense region of Misiones, Argentina," Forest Ecology and Management, vol. 99, no. 1-2, pp. 237-246, 1997.

[15] A. K. Zaidey, A. Arifin, I. Zahari et al., "Characterizing soil properties of lowland and hill dipterocarp forests at Peninsular Malaysia," International Journal of Soil Science, vol. 5, no. 3, pp. 112-130, 2010.

[16] J. J. Kendawang, J. Sabang, S. Tanaka et al., "Effects of shifting cultivation on soil ecosystems in Sarawak, Malaysia: I. Slash and burning at Balai Ringin and Sabal experimental sites and effect on soil organic matter," Soil Science \& Plant Nutrition, vol. 50, no. 5, pp. 677-687, 2004.

[17] M. E. Wasli, H. Sani, S. Y. Ho et al., "Preliminary assessment on the growth performance of Dryobalanops beccarii Dyer planted under enrichment planting technique at Gunung Apeng Forest Reserve," Kuroshio Science, vol. 8, pp. 45-52, 2014.

[18] M. Perumal, M. E. Wasli, S. Y. Ho, J. Lat, and H. Sani, "Survivorship and growth performance of Shorea macrophylla (de Vriese) after enrichment planting for reforestation purpose at Sarawak, Malaysia," Online Journal of Biological Sciences, vol. 17, no. 1, pp. 7-17, 2017.

[19] M. Perumal, M. E. Wasli, S. Y. Ho, J. Lat, and H. Sani, "Soil morphological and physicochemical properties at reforestation sites after enrichment planting of Shorea macrophylla in Sampadi Forest Reserve, Sarawak, Malaysia," Borneo Journal of Resource Science and Technology, vol. 5, no. 2, pp. 28-34, 2015.

[20] S. Appanah and G. Weinland, Planting Quality Timber Trees in Peninsular Malaysia, Forest Research Institute of Malaysia, Kepong, Kuala Lumpur, Malaysia, 1993.

[21] A. Arifin, S. Tanaka, S. Jusop, N. M. Majid, Z. Ibrahim, and K. Sakurai, "Rehabilitation of degraded tropical rainforest in Peninsular Malaysia with a multi-storied plantation technique of indigenous dipterocarp species," Japanese Journal of Forest Environment, vol. 50, pp. 141-152, 2008.

[22] H. Affendy, M. Aminuddin, W. Razak, A. Arifin, and A. R. Mojiol, "Growth increments of indigenous species planted in secondary forest area," Journal of Forestry Research, vol. 3, no. 1, pp. 23-28, 2009.

[23] M. Z. Hamzah, A. Arifin, A. K. Zaidey et al., "Characterizing soil nutrient status and growth performance of planted dipterocap and non-dipterocarp species on degraded forest land in Peninsular Malaysia," Journal of Applied Sciences, vol. 9, no. 24, pp. 4215-4223, 2009.

[24] D. K. Jha, G. D. Sharma, and R. R. Mishra, "Soil microbial population numbers and enzyme activities in relation to altitude and forest degradation," Soil Biology \& Biochemistry, vol. 24, no. 8, pp. 761-767, 1992.

[25] M. M. Sena, R. J. Poppi, R. T. Frighetto, and P. J. Valarini, "Avaliação do uso de métodos quimiométricos em análise de solos," Química Nova, vol. 23, no. 4, pp. 547-556, 2000.

[26] J. Domínguez, M. A. Negrín, and C. M. Rodríguez, "Soil chemical characteristics in relation to fusarium wilts in banana crops of Gran Canaria Island (Spain)," Communications in Soil Science and Plant Analysis, vol. 27, no. 13-14, pp. 2649-2662, 1996.

[27] B. D. Seelig, J. L. Richardson, and R. E. Knighton, “Comparison of statistical and standard techniques to classify and delineate sodic soils," Soil Science Society of America Journal, vol. 55, no. 4, pp. 1042-1048, 1991.

[28] M. Perumal, M. E. Wasli, and H. Sani, Relationship between soil fertility and growth performance of planted Shorea macrophylla at reforestation sites of Sampadi Forest Reserve, Sarawak, Malaysia [master thesis], Universiti Malaysia Sarawak, Kota Samarahan, Sarawak, Malaysia, 2014.

[29] E. F. Moran, E. S. Brondizio, J. M. Tucker, M. C. Da SilvaForsberg, S. McCracken, and I. Falesi, "Effects of soil fertility and land-use on forest succession in Amazônia," Forest Ecology and Management, vol. 139, no. 1-3, pp. 93-108, 2000.

[30] D. Lu, E. Moran, and P. Mausel, "Linking Amazonian secondary succession forest growth to soil properties," Land Degradation \& Development, vol. 13, no. 4, pp. 331-343, 2002.

[31] J. P. Andriesse, The Soils of West Sarawak (East Malaysia), 1. Memoir, Ed., Soils Division, Department of Agriculture, Sarawak, Malaysia, 1972.

[32] Meteorological Department, Weather Data (Air Temperature) 2001-2010, Meteorological Department, Sarawak, Kuching, Malaysia, 2010.

[33] S. C. Teng, Keys to Soil Classification of Sarawak, Agriculture Department of Sarawak, 2004.

[34] Soil Survey Staff, Keys to Soil Taxonomy, US, Department of Agriculture and Natural Resources Conservation Services, Washington, D.C., Wash, USA, 12th edition, 2014.

[35] Forest Department Sarawak, "Planted Forests in Sarawak," in Proceedings of an International Conference, pp. 16-17, Sarawak , Malaysia, February 1998.

[36] M. E. Wasli, S. Tanaka, J. J. Kendawang et al., "Vegetation conditions and soil fertility of fallow lands under intensified shifting cultivation systems in Sarawak, Malaysia," Tropics, vol. 18, no. 3, pp. 115-126, 2009.

[37] M. E. Sumner and B. A. Stewart, Soil Crusting: Chemical and Physical Processes, Lewis Publishers, Boca Raton, FL, USA, 1st edition, 1992.

[38] J. A. McKeague, Manual on Soil Sampling and Methods of Analysis, Canadian Soil Survey Committee, Ottawa, Ontario, Canada, 1976.

[39] N. C. Banning, C. D. Grant, D. L. Jones, and D. V. Murphy, "Recovery of soil organic matter, organic matter turnover and nitrogen cycling in a post-mining forest rehabilitation chronosequence," Soil Biology \& Biochemistry, vol. 40, no. 8, pp. 2021-2031, 2008.

[40] J. M. Bremner and C. S. Mulvaney, "Methods of soil analyses, part 2: chemical and mineralogical properties," in NitrogenTotal, R. H. Miller and D. R. Keeney, Eds., pp. 595-624, American Society of Agronomy, Soil Science Society of America, Madison, WI, USA, 1982.

[41] R. H. Bray and L. T. Kurtz, "Determination of total, organic, and available forms of phosphorus in soils," Soil Science, vol. 59, no. 1, pp. 39-46, 1945.

[42] S. Kuo, "Methods of soil analysis, part 3: chemical methods," in Phosphorus, D. L. Sparks, P. N. Page, M. A. Tabatabai, C. T. Johnston, and M. E. Summer, Eds., SSSA Book Series no. 5, pp. 869-919, Soil Science Society of America, Inc. and American Society of Agronomy, Inc., Wisconsin, WI, USA, 1996.

[43] G. W. Gee and J. W. Bauder, "Methods of soil analysis, part 1: physical and mineralogical methods," in Particle-Size Analysis, A. Klute, Ed., pp. 399-404, Soil Science Society of America, Inc. and America Society of Agronomy, Inc., Madison, WI, USA, 2nd edition, 1986. 
[44] K. H. Tan, Soil Sampling, Preparation and Analysis, Taylor and Francis, 2nd edition, 2005.

[45] M. Perumal, M. E. Wasli, and J. Lat, "Estimating soil fertility status using soil quality indices at reforestation sites in Sampadi Forest Reserve, Sarawak, Malaysia," in Proceedings of the 2nd Regional Taxonomy and Ecology Conference, I. Jusoh, I. Ipor, A. S. A. Puad, and R. Hassan, Eds., pp. 275-287, Universiti Malaysia Sarawak, Sarawak, Malaysia, 2016.

[46] A. Arifin, S. Tanaka, S. Jusop et al., "Soil characteristics under rehabilitation of degraded forest land in Perak, Peninsular Malaysia," Pedologist, vol. 51, pp. 76-88, 2007.

[47] S. Tanaka, S. Tachibe, M. E. B. Wasli et al., "Soil characteristics under cash crop farming in upland areas of Sarawak, Malaysia," Agriculture, Ecosystems \& Environment, vol. 129, no. 1-3, pp. 293-301, 2009.

[48] S. Tanaka, M. E. Wasli, T. Kotegawa et al., "Soil properties of secondary forests under shifting cultivation by the Iban of Sarawak, Malaysia in relation to vegetation condition," Tropics, vol. 16, no. 4, pp. 385-398, 2007.

[49] S. Ohta, K. Morisada, N. Tanaka, Y. Kiyono, and S. Effendi, "Are Soils in Degraded Dipterocarp Forest Ecosystems Deteriorated? A Comparison of Imperata Grasslands, Degraded Secondary Forests, and Primary Forests," in Rainforest Ecosystems of East Kalimantan, vol. 140 of Ecological Studies, pp. 49-57, Springer Japan, Tokyo, 2000.

[50] J. Boonyanuphap, K. Sakurai, and S. Tanaka, "Soil nutrient status under upland farming practice in the Lower Northern Thailand," Tropics, vol. 16, no. 3, pp. 215-231, 2007.

[51] M. H. Akbar, O. H. Ahmed, A. S. Jamaluddin et al., "Differences in soil physical and chemical properties of rehabilitated and secondary forests," American Journal of Applied Sciences, vol. 7, no. 9, pp. 1200-1209, 2010.

[52] P. H. Nye and D. J. Greenland, "Changes in the soil after clearing tropical forest," Plant and Soil, vol. 21, no. 1, pp. 101-112, 1964.

[53] S. Ishizuka, S. Tanaka, K. Sakurai et al., "Characterization and distribution of soils at Lambir Hills National Park in Sarawak, Malaysia, with special reference to soil hardness and soil texture," Tropics, vol. 8, no. 1/2, pp. 31-44, 1998.

[54] A. S. R. Juo and A. Manu, "Chemical dynamics in slash-andburn agriculture," Agriculture, Ecosystems \& Environment, vol. 58, no. 1, pp. 49-60, 1996.

[55] C. P. Giardina, R. L. Sanford Jr., I. C. Døckersmith, and V. J. Jaramillo, "The effects of slash burning on ecosystem nutrients during the land preparation phase of shifting cultivation," Plant and Soil, vol. 220, no. 1-2, pp. 247-260, 2000.

[56] W. Etsuko, K. Sakurai, Y. Okabayashi, L. Nouanthasing, and A. Chanphengxay, "Soil fertility and farming systems in a slash and burn cultivation area of Northern Laos," Southeast Asian Studies, vol. 41, no. 4, pp. 519-537, 2004.

[57] S. Ohta, S. Effendi, N. Tanaka, S. Miura, S. Ohta, and S. Effendi, "Ultisols of lowland Dipterocarp forest in East Kalimantan, Indonesia: III. Clay minerals, free oxides, and exchangeable cations," Soil Science \& Plant Nutrition, vol. 39, no. 1, pp. 1-12, 1993.

[58] B. Soto and F. Diaz-Fierros, "Interactions between plant ash leachates and soil," International Journal of Wildland Fire, vol. 3, no. 4, pp. 207-216, 1993.

[59] S. Ohta and S. Effendi, "Ultisols of 'lowland Dipterocarp forest' in East Kalimantan, Indonesia: II. Status of carbon, nitrogen, and phosphorus," Soil Science \& Plant Nutrition, vol. 38, no. 2, pp. 207-216, 1992.
[60] P. T. Alvim and F. P. C. Rosand, "Um novo sistema de representacao grafica da fertilidade de solos para cacao," Cacao Atualidades, vol. 11, pp. 2-6, 1974.

[61] D. P. Schachtman, R. J. Reid, and S. M. Ayling, "Phosphorus uptake by plants: from soil to cell," Plant Physiology, vol. 116, no. 2, pp. 447-453, 1998.

[62] K. W. Perrott, S. U. Sarathchandra, and J. E. Waller, "Seasonal storage and release of phosphorus and potassium by organic matter and the microbial biomass in a high-producing pastoral soil," Australian Journal of Soil Research, vol. 28, no. 4, pp. 593608, 1990.

[63] E. Frossard, L. M. Condron, A. Oberson, S. Sinaj, and J. C. Fardeau, "Processes governing phosphorus availability in temperate soils," Journal of Environmental Quality, vol. 29, no. 1, pp. 15-23, 2000.

[64] C. R. Chen, L. M. Condron, M. R. Davis, and R. R. Sherlock, "Seasonal changes in soil phosphorus and associated microbial properties under adjacent grassland and forest in New Zealand," Forest Ecology and Management, vol. 177, no. 1-3, pp. 539-557, 2003. 

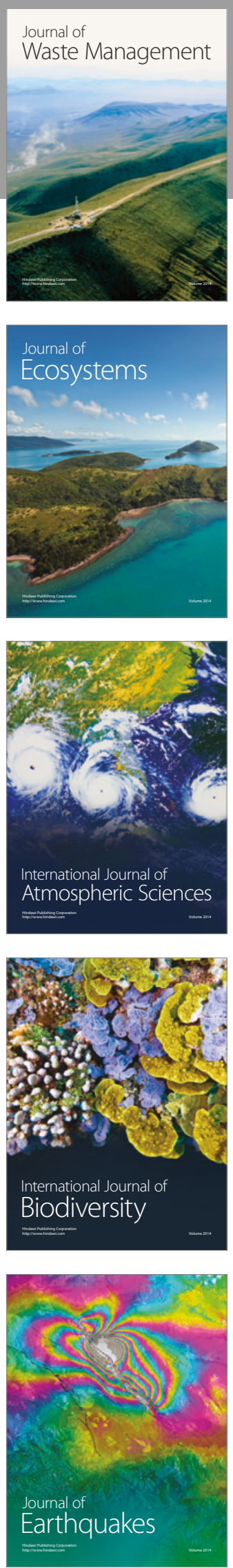
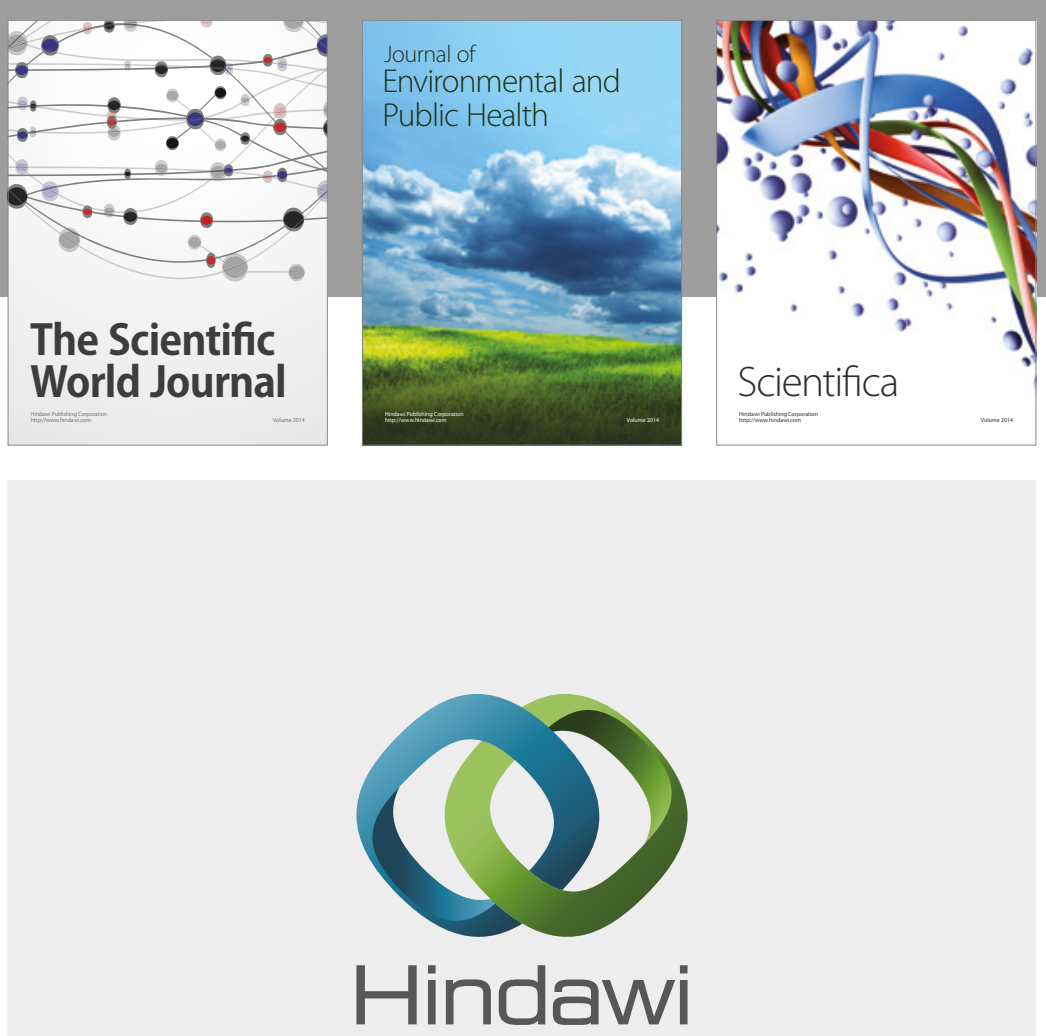

Submit your manuscripts at

https://www.hindawi.com
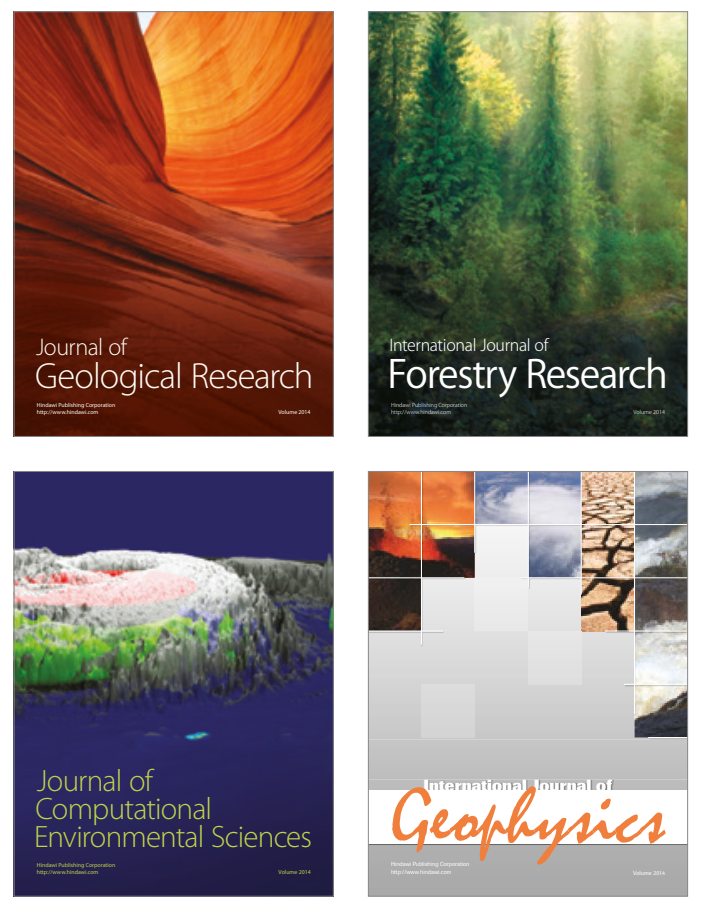
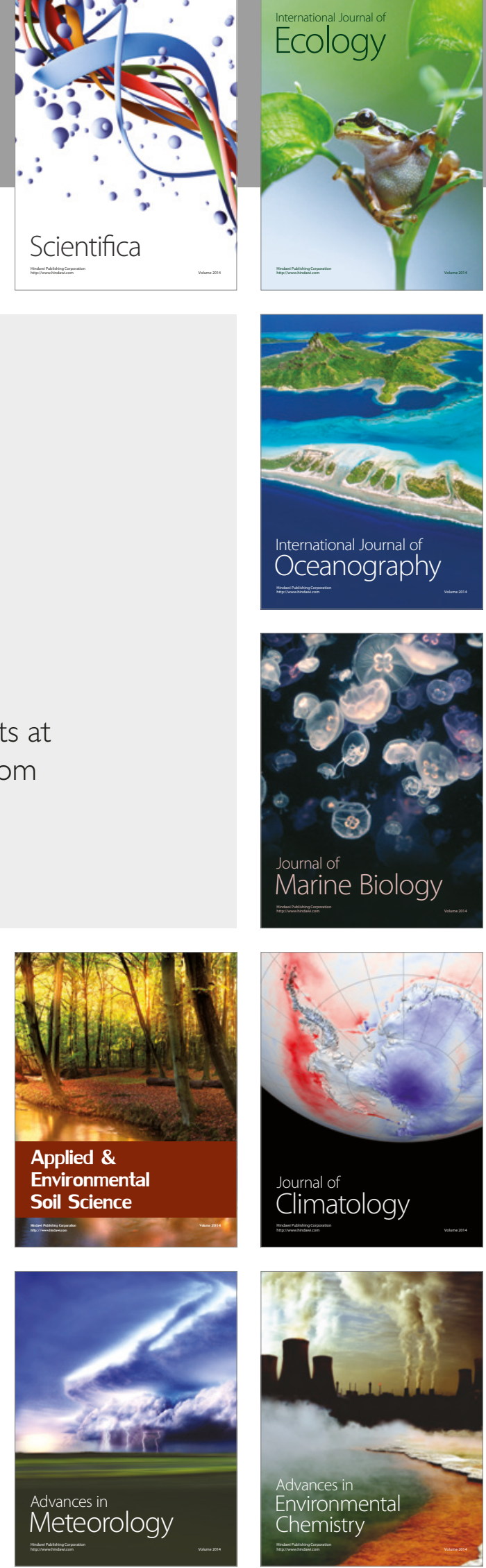